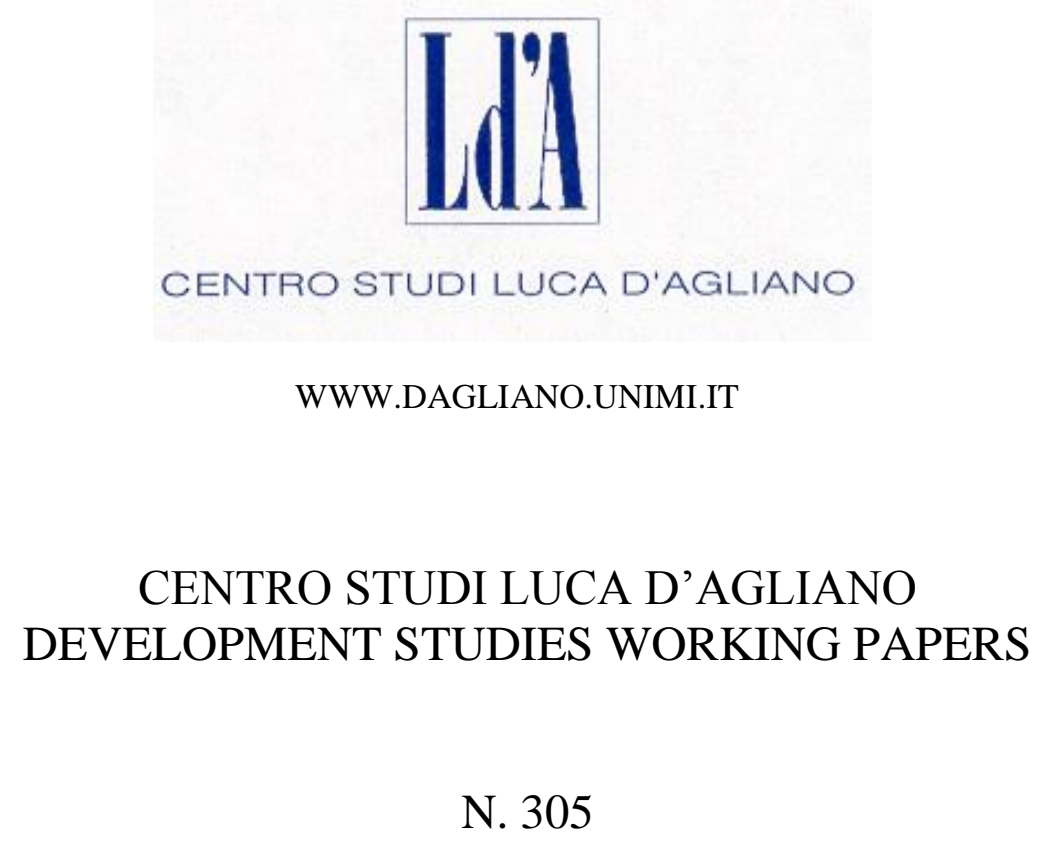

November 2010

IMF Lending in Low-and Middle-Income Countries in the Wake of the Global Crisis

\author{
Andrea F. Presbitero* \\ Alberto Zazzaro*
}

* Università Politecnica delle Marche 


\title{
IMF lending in Low- and Middle-Income Countries in the Wake of the Global Crisis
}

\author{
Andrea F. Presbitero \\ Alberto Zazzaro*
}

November 13, 2010

\begin{abstract}
In the wake of the global crisis the International Monetary Fund (IMF) increased its exposure to low- and middle-income countries and boosted the overhaul of its lending approach to enhance its role in preventing crises. This paper tests whether IMF lending has targeted countries most affected by the crisis in order to dampen contagion effects and assesses to what extent the Fund's strategy has been driven by political-economy interests of its major shareholders. Results show that political similarity between borrowers and G7 governments has influenced the participation in IMF programs, especially where the crisis was severe. In addition, the extent of the crisis and the economic interest of Western countries have affected the size of the loan.
\end{abstract}

JEL Classification: F33, F34, F35, O11

Key words: Global crisis, IMF programs, Washington Consensus, growth.

\footnotetext{
*Andrea F. Presbitero (corresponding author), Department of Economics - Università Politecnica delle Marche (Italy), Money and Finance Research group (MoFiR) and Centre for Macroeconomic and Finance Research (CeMaFiR). E-mail: a.presbitero@univpm.it; personal webpage: https://sites.google.com/site/presbitero/. Alberto Zazzaro, Department of Economics - Università Politecnica delle Marche (Italy), Money and Finance Research group (MoFiR) and Centro per la Formazione in Economia e Politica dello Sviluppo Rurale (CFEPSR). Email: a.zazzaro@univpm.it; personal webpage: http://utenti.dea.univpm.it/zazzaro/. The authors are grateful to Alessia Amighini and Christopher Kilby for providing data on, respectively, FDI and UN votes. They also wish to thank for insightful suggestions Marco Arnone, Dirk Bezemer, Paolo Paesani, and participants in seminars at the University of Perugia, "The Global Crisis" Conference (University of Siena), "Real and Financial Causes and Consequences of 2008 Crises" Conference (University of Rome "La Sapienza"), "The Adriatic-Balkan Area from Transition to Integration" Conference (Università Politecnica delle Marche), "Can It Happen Again?" Conference (University of Macerata).
} 


\section{Introduction}

Starting in the middle of 2007 from a narrow sector of the US financial industry, the crisis propagated all over the globe in the space of a few months, dropping wealthy, emerging and poor countries into the worst economic turmoil since the Great Depression of the 1930s. In emerging and developing economies, the difference between the pre-crisis and the latest International Monetary Fund (IMF) GDP growth projections over the period 2008-2011, an acceptable approximation for the actual gravity of the crisis, is more than 8 percent. The vulnerability of these countries to the global recession is exacerbated by the extraordinary dependence of their economies on volatile resources from industrialized countries, such as exports of primary commodities, private capital inflows, remittances and foreign assistance (International Monetary Fund, 2009; World Bank, 2009). In addition, poor countries lack resources, instruments and safety nets to cope with the crisis and mitigate its effects on displaced workers and vulnerable people. As the IMF managing director Dominique Strauss-Kahn emphatically said:

"I am deeply concerned about the potential humanitarian costs of this crisis [...] low-income countries have to safeguard the funds they have for education and infrastructure, while boosting safety nets to protect the most vulnerable [...] the financing needs are substantial, and they are very urgent. I therefore want to use this opportunity to call on the international community to provide the financing the most vulnerable countries need to preserve their hard-won gains and prevent a humanitarian crisis." (Strauss-Kahn, 2009, pp. 9-10).

In response to the global financial crisis and such an influential admonition, the International Financial Institutions (IFI) have greatly boosted their lending to developing countries to help them cope with the crisis and to sustain the economic recovery. The IMF, in particular, reversed a downsizing process and, after the April 2009 G-20 summit in London, it increased its lending capacity to USD 750 billion. Besides the budget increase, there is an ongoing and intense debate about the future of the IMF's mandate, about the necessity to complement the traditional functions of providing short-term financial assistance and promoting external balance stability in member countries with a wider responsibility of crisis prevention, supporting financially prudent countries that, although not suffering actual reserve shortage, are vulnerable to external shocks (Meltzer, 2010; International Monetary Fund, 2010)ํ․

However, the resurgence of the IMF in the policy arena has also revived slumbering concerns and criticisms with regard to the Fund's policy-oriented lending behavior which should have benefited industrialized countries (Payer, 1974). In the last decade, the Bretton Woods institutions have been the main targets of the massive no global protest which started in Seattle in 1999. In particular, the IMF was subject to harsh criticisms for its approach to the financial crises of the 1990s in Southeast Asia and Latin America and the handling of the transition of former communist countries to free markets, accused of being too sensitive to the political and economic interests of their major shareholders, who, de facto, control the IMF Executive Board ${ }^{2}$.

\footnotetext{
${ }^{1}$ Following this debate, the IMF overhauled its lending framework, increasing the flexibility of the lending instruments and moving towards an ex-ante policy conditionality, as testified by the introduction of the Flexible Credit Line (FCL) and the proposal of the Precautionary Credit Line (PCL), designed to prevent crisis in countries with sound fundamentals and policies.

${ }^{2}$ Votes on the IMF Executive Boards are based on the size of the quotas with which each member country contributes to the Fund, such that the US holds $16.74 \%$ of the votes and G7 countries (Canada, France, Germany, Italy, Japan, the United Kingdom and United States) 44.39\% (see: http://www.imf.org/external/np/sec/memdir/members.htm). This means that G7 and the US have an actual veto power on decisions requiring qualified majorities of $70 \%$ and $85 \%$ and a de facto veto power on lending decisions requiring a simple majority, which in fact are informally based on a consensual decision-making process
} 
Stiglitz (2002) and Sachs (2004) gave more solid arguments to the opponents of the "Washington consensus", reaching a broader progressive audience extraneous to the anti-globalization movement. But criticisms have been leveled nor only from the left, but also from the right: the IMF has been accused of having surrendered too often to the pressures of politics and the interests of the internal bureacracy, with the effect of having encouraged moral hazard on the part of borrowing countries and other private creditors (Dreher and Vaubel, 2004).

As a result of these criticisms, a vast scientific literature ranging from political science to political economy has flourished, discussing the determinants of IMF loan arrangements and stressing the overwhelming influence of the United States and Group of 7 (G7) in shaping its lending decisions. For example, there is evidence that countries that are foreign policy allies of the USA are more likely to access IMF and World Bank programs (Thacker, 1999; Barnebeck Andersen, Harr and Tarp, 2006; Kilby, 2009b) and that developing countries use their temporary seat on the United Nations Security Council (UNSC) to vote along with the USA delegation in order to gain favorable economic treatment from the Bretton Woods institutions (Dreher, Sturm and Vreeland, 2009a,b). In addition, there are indications that participation in an IMF program is positively influenced by the existence of US commercial and financial interests in the borrowing country (Oatley and Yackee, 2004; Barro and Lee, 2005; Broz and Hawes, 2000; Copeletovich, 2010a).

The risk for the IMF of being captured by the specific interests of their major shareholder countries is especially great at a time, like the present one, in which these countries are experiencing a deep domestic economic crisis. When the availability of resources for bilateral aid is much lower, the pressure to reward the policy "friendship" of foreign nations by drawing on multilateral financial resources is obviously stronger (Dreher, Sturm and Vreeland, 2009b). In addition, as the crisis is global, the interest in using IMF money is shared across the governments of the major member states, thereby increasing the possibility of finding a consensus within the IMF Executive Board where each of them has an incentive to support loans for each other's policy and economic foreign partners (Copeletovich, 2010b).

In this paper, we reconsider the political influence hypothesis by focusing on the lending arrangements signed by the IMF and low- and middle-income countries (LMICs) during the crisis, from January 2008 to June 2010. Besides the intrinsic importance of this period, by limiting the analysis to the IMF response to the current global financial crisis we overcome the problem of the episodic nature of the IMF lending policy which undermines the significance of large sample studies (Bird and Rowlands, 2009, 2010) ${ }^{3}$. In fact, we may assume that in the two-year period considered, strongly characterized by a shared condition (the global crisis) among member states, the IMF lending policy has not undergone major changes, by making the investigation of its main determinants a viable and significant research objective. In addition, the systemic nature of the global crisis makes it the ideal context to test whether the IMF has played a stabilization role by channeling financial assistance to countries which are expected to suffer more from the crisis in medium run, regardless of their actual foreign imbalances and poor economic performance.

driven by the advanced countries dominating the Executive Board (van Houtven (2002); as for now, just the support of the executive directors expressed by Belgium, the Netherlands or Spain, all sharing a common currency with three of the G7 countries, gives a majority voting power to this "augmented G7" in the Executive Board). Recently, the IMF Executive Board has approved a broad set of governance reforms which are scheduled to be effective in late 2012 and are going to shift quotas and voting power to emerging and developing countries. For a broad discussion of the political influence hypothesis see Fratianni and Pattison (2005).

${ }^{3}$ As Graham Bird notes, the high variability and modest explanatory power of the existing evidence, rather than a failure of the literature to find a well-founded explanation of IMF arrangements, would simply indicate "that there is no one overall explanation [... and that] certain things are important in some cases but not in others, such that their significance effectively cancels out in large sample studies" (Bird, 2007, p. 704). 
We therefore test whether the likelihood of starting a lending program with the IMF and the size of the loan agreed depend on the medium-run severity of the crisis in the recipient country and whether they are greater in member states who are political allies and commercial/industrial/financial partners of IMF major shareholders. To anticipate our main results, we find that the political similarity with G7 countries rises the probability of entering a loan agreement, while the harsher the crisis in the country, the larger the loan granted by the IMF. However, the severity of the crisis makes no difference for the participation in IMF programs, except from the low- and middle-income member countries which are political allies of G7 governments. Financial exposure of foreign banks and the amount of G7 direct foreign investments in an LMIC significantly increase the size of the loan the latter can obtain, but does not make the probability of access to IMF programs higher.

The rest of the paper proceeds as follows. Section 2 appraises the existing literature on the influence of the United States and other powerful member states on the IMF lending policy. Section 3 presents the empirical strategy, showing some descriptive evidence of the IMF loans agreed since 2008 (Section 3.1) and introducing the econometric model and the variables (Section 3.2). The main results and some robustness exercises are discussed in Sections 4 and 5, while Section 6 concludes. All Tables are reported in the Appendix.

\section{Do IMF major shareholders' interests drive IMF lending?}

Much empirical research has been devoted to examining the motivations of the Fund and member countries for entering into a lending arrangement ${ }^{4}$. Some studies investigate this issue per se, looking either at the loan amount agreed to by the Fund (Bird and Orme, 1981; Cornelius, 1987; Oatley and Yackee, 2004) or at the decision to start a new lending program (Joyce, 1992; Knight and Santaella, 1997; Thacker, 1999; Sturm, Berger and De Haan, 2005; Barnebeck Andersen, Harr and Tarp, 2006; Harrigan, Wang and El-Said, 2006; Broz and Hawes, 2000). In addition, in the last decade the participation issue has been addressed by several studies looking at the effects of IMF programs on borrowers, in order to correct for selection bias and endogeneity problems (Garuda, 2000; Przeworski and Vreeland, 2000; Barro and Lee, 2005; Dreher, 2006b; Eichengreen, Gupta and Mody, 2006; Biglaiser and DeRouen Jr, 2010). Results vary with sample periods, countries, IMF programs, empirical models, variable definitions and econometric methodologies, such that the IMF's lending strategy can be defined as unpredictable (Bird and Rowlands, 2010). However, a firm indication ensuing from this literature is that the likelihood of entering an IMF arrangement, the size of approved loans and the amount of credit actually drawn respond not only to the macroeconomic and political conditions of the borrowing country, but also to its political and economic links with IMF influential shareholders ${ }^{5}$.

In an attempt to examine the accusation leveled against the IMF of serving the specific interests of their major shareholders more than its mandate, researchers have included a number of variables reflecting the political "friendship" and economic ties between the IMF major shareholders and the recipient countries. The idea is that the US and other G7 administrations use their influence on IMF decisions (see above, footnote 1) to reward foreign policy allies with the Fund's financial assistance ${ }^{6}$ and to safeguard the economic interests of their companies in

\footnotetext{
${ }^{4}$ Joyce (2006), Bird (2007) and Steinwand and Stone (2008) provide comprehensive reviews of this literature.

${ }^{5}$ Other authors have suggested that the IMF is a complex organization governed by bureaucrats who pursue their own agendas aimed at maximizing the budget of their office, personal prestige and career opportunities (Vaubel, 1986, 1991; Fratianni and Pattison, 2005). In this view, the IMF decision to assist a member country would reflect the interests of its management and staff to gain authority and reputation, both within the Fund and with respect to their home government.

${ }^{6}$ According to Dreher, Sturm and Vreeland (2009b), the major member states of the IMF may prefer to reward the friendship of a country by easing access to Fund programs rather than by direct aid packages for
} 
countries that have crashed into a debt crisis by driving the Fund's resources toward these countries.

\subsection{Political interests}

The most commonly used indicators for the degree of proximity of foreign policy preferences between an IMF member state and its main shareholders is the affinity in the voting pattern at the United Nations General Assembly (UNGA) ${ }^{7}$. The rationale behind this measure is that the US and other G7 governments can, and actually do, trade their vote on the start, size and content of lending programs in the IMF Executive Board in exchange for support on issues being voted upon in the UNGA. For example, as one can read in the Report to Congressional Committees of the U.S. General Accounting Office (General Accounting Office, 2001), there were 60 legislative mandates as of November 2000 that either sought to have the U.S. Executive Director (USED) use its voice at the IMF to promote U.S. foreign policy interests or explicitly instruct the USED to use its vote at the IMF to pursue a policy objective (for example, the US Code - Section 286AA stated "the Secretary of the Treasury shall instruct the United States Executive Director of the Fund to actively oppose any facility involving use of Fund credit by any Communist dictatorship, unless ..." certain conditions are met).

All in all, empirical results tend to provide good arguments in favor of the political influence hypothesis, even if the statistical robustness is limited and interpretation is not always straightforward. Barro and Lee (2005) and Eichengreen, Gupta and Mody (2006) measure the foreign policy similarity of a country to the USA and major European countries (France, Germany and the UK) as the fraction of times they vote identically in UNGA plenary votes in a given year. Yet, the results they report are inconsistent. While Barro and Lee (2005) documented a positive and significant effect of UNGA voting affinity on both the likelihood of signing an IMF program and the amount of money received, Eichengreen, Gupta and Mody (2006) showed that similarity in UNGA voting patterns to the USA significantly decreases the probability of an IMF member state adopting a program. Copeletovich (2010b) also looks at the absolute political proximity using the Gartzke's United Nations Affinity S-score computed on the rankorder correlations of roll-call voting positions in the UNGA (Gartzke, 1998): he found that a greater voting affinity with the Group of 5 (France, Germany, Japan, the United Kingdom, and the United States) does not affect the likelihood of member countries participating in IMF programs, while it increases the amount of loans granted by the Fund.

As Thacker (1999, p. 53) notes, however, "not all the UN votes are equally important". Therefore, he suggests refining the measure of foreign policy similarity by including only the UNGA votes on issues considered crucial by the US Department of State. He find that a country increases the probability of receiving an IMF loan if it moves its voting pattern towards the US position, but not if it persistently votes in line with the US Administration. Thacker's results are partially confirmed by Broz and Hawes (2000), who however did not document any effect for voting alignment with France, the United Kingdom and Japan, and by Pop-Eleches (2008), who found that the positive effect of a change in UN voting vis-à-vis the United States holds for post-communist but not for Latin American countries. By contrast, Oatley and Yackee (2004) showed that the amount of credit extended by the IMF is positively correlated with the degree of absolute vote alignment between the recipient member state and the USA, but not with the change in this alignment.

both political (like shadowing the vote exchange) and economic (like minimizing the commitment of financial resources) reasons.

${ }^{7}$ Other variables considered in the literature are the bilateral money and military aid from the USA and G7 countries (Oatley and Yackee, 2004; Eichengreen, Gupta and Mody, 2006; Stone, 2008) or the sign of a peace treaty with Israel (Harrigan, Wang and El-Said, 2006). 
Barnebeck Andersen, Harr and Tarp (2006) propose a further refinement of the political friendship measure. They start by observing that similarity in the voting patterns at the UNGA could be due to similarity in the foreign policy preferences and, as such, it does not need to be rewarded. The US and G7 governments would trade their influence over the IMF Executive Board only for lobbying nations whose overall UNGA voting pattern is dissimilar to their own. This means that neither absolute alignment with IMF major shareholders' UNGA voting positions nor the shift toward them over time should increase, per se, the probability of a country accessing IMF lending programs. The latter, instead, would be affected by costly voting concessions to IMF major shareholders. Consistently, Barnebeck Andersen, Harr and Tarp (2006) re-estimate Thacker's model and argue that what really matters for increasing the probability of receiving an IMF loan is the country's deviation from its normal voting pattern toward the US position on votes considered important by the US administration ${ }^{8}$.

Finally, Dreher, Sturm and Vreeland (2009b) indirectly corroborate the idea that a country has to make some concessions in order to gain the support of IMF major shareholders, showing that countries that serve as temporary members on the United Nations Security Council, the most important UN decisional organ, have a $6 \%$ higher probability of participating in an IMF program.

\subsection{Economic interests}

Other authors have argued that IMF programs are more likely and generous in countries where trade, investment and financial exposure of the Fund's major shareholders' firms and banks are significant. On closer inspection, however, theoretical arguments recommend more caution in drawing such a conclusion. While it is reasonable to believe that Western administrations may exert influence on IMF lending policy in order to safeguard the foreign exposure of their companies - especially when they constitute a group which is homogeneous and large enough to lobby for support -, it is also conceivable that importers, exporters and multinational companies tend to operate and invest in countries which are economically and politically more stable and less in need of IMF intervention.

Not surprisingly, the empirical evidence on the economic interest hypothesis is largely inconclusive. For instance, Barro and Lee (2005) found that the intensity of trade with the US increases the probability of participation in, and the amount of, IMF agreements, although the same variable computed for France, Germany and the UK is insignificant. Similarly, insignificant effects of commercial proximity to the IMF large shareholders are reported by Thacker (1999), Sturm, Berger and De Haan (2005) and Eichengreen, Gupta and Mody (2006), while Bird and Rowlands (2001) showed that higher US exports are associated with a lower probability of signing a loan with the Fund. By contrast, Breen (2010) documented a positive effect of commercial links, measured by G5 exports, both on the probability of receiving an IMF loan and on its size. Whereas foreign trade typically involves a great number of small and mediumsized enterprises which are unlikely to coordinate to lobby the home government to promote their commercial interests on the IMF Executive Board, Thacker (1999) considers the stock of US foreign direct investment (FDI). He found that recipients of American FDI have a lower probability of receiving an IMF loan, although the effect is statistically non-significant.

A number of studies have also looked at the exposure of industrialized countries' banks, with mixed results. Broz and Hawes (2000) found that countries more exposed with US and German banks are more likely to participate in IMF programs, receiving greater loans, a result

\footnotetext{
${ }^{8}$ Similarly, Kilby (2009b, p. 54) builds a 0-1 US friendship variable and classifies a country as a US friend in a given year "if it was more closely aligned with the U.S. on 'important' UN votes than on all UN votes" in the previous year. Using the friendship dummy, he confirms the findings of Barnebeck Andersen, Harr and Tarp (2006) with regard to the participation in World Bank assistance programs.
} 
recently confirmed by Breen (2010) focusing on G5 bank exposure. Oatley and Yackee (2004) confirm this result for US banks but not for German ones, while Sturm, Berger and De Haan (2005) and Eichengreen, Gupta and Mody (2006) showed that also the exposure of US banks is not significant. Copeletovich (2010a) explains this contrasting evidence focusing on the G5 financial interests, proxied by their bank exposure, and taking into account the role played by the heterogeneity of the preferences of G5 administrations. The higher the bank exposure in a country, the larger is the IMF loan, but this effect decreases and turns negative when the borrowing country's debt is unevenly distributed across G5 countries; in that case, the IMF staff are likely to propose smaller loan to the Executive Board in order to maximize the change of approval in a situation in which disagreement between its permanent members is greater.

\section{Data, methodology and descriptive statistics}

\subsection{IMF loan arrangements in response to the crisis}

To assess the stabilization role played by the IMF during the crisis and the impact of major shareholders' specific interests in shaping the Fund's policy, we focus on the lending programs that started in developing countries between January 2008 and June 2010. Since January 2008, the Fund has extended 67 loan arrangements to 56 countries for over USD 303 billion. Four of these loan arrangements are excluded from the sample since borrowers are high-income countries (Antigua and Barbuda, Greece, Hungary and Iceland) ${ }^{9}$. In addition, since our research question concerns the response of IMF to the global crisis in LMICs and the unit of observation is the country, loans to members participating in more than one program in the sample periods (Armenia, Colombia, El Salvador, Malawi, Maldives, Mexico, Moldova, Poland and Seychelles) are treated as a single arrangement ${ }^{10}$. In this case, we consider the sum of amounts agreed in each separate IMF loan as the size of the whole loan and we take the lending facility and the date of arrangement of the largest loan as references for the lending arrangement. Finally, we also exclude Liberia from the sample as it represents an outlier, having signed two agreements amounting to more than its national GDP. In the end, we are able to identify 51 low- and middle-income borrowers, as reported in Table 1, accounting for a total loans of USD 244 billion.

A first inspection of the data shows that more than $60 \%$ of loans to LMICs were directed to just three countries - Mexico, Poland and Colombia, for which the FCL was approved while less than $2 \%$ targeted 26 poor countries on concessional terms through the Extended Credit Facility (formerly Poverty Reduction and Growth Facility - PRGF), the Exogenous Shocks Facility and the new Standby Credit Facility. Yet, low-income countries account for $1.4 \%$ of lending, while their shares in total GDP and population in the sample are $5.2 \%$ and $37.2 \%$ respectively. Also the average size of the loan changes significantly between low- and middle-income countries: poor countries borrowing at concessional terms through the ECF (ESF) receive a loan which is, on average, $2.4 \%(1.5 \%)$ of GDP, while the average Stand-by

\footnotetext{
${ }^{9}$ Data on lending arrangements are reported on a monthly basis by the IMF and published online at: http://www.imf.org/external/np/fin/tad/extarr1.aspx.

${ }^{10}$ Considering the loan as the unit of observation poses at least two problems. The first is related to the fact that, working in a cross section, only the comparison between countries with and without the loan is meaningful. Taking loans as the unit of observation would duplicate countries with a loan, while not the others (imagine a sample of 100 countries, 30 of which received a loan and 10 five loans over the sample period. Taking the country as the unit of observation, we can compare 40 borrowing to 60 non-borrowing countries; taking the loan as the unit of observation, 80 loan observations with 60 non-loan observations). Related to this, if we use the loan as a dependent variable the effect of country-specific variables, which are repeated for the multi-loan countries, is inflated, leading to biased standard errors.
} 
Arrangement signed with middle-income countries amounts to $7.9 \%$ of GDP ${ }^{11}$.

\subsection{The empirical strategy}

\subsubsection{The model}

We model the IMF lending decision as a two-step process, the first being the choice whether or not to lend and the second concerning the amount of resources to lend. Hence, a standard linear model for estimating the determinants of the amount of IMF loans cannot be used because of the sample selection bias, given that we observe the dependent variable (the loan size) only for countries which are under an IMF program. Therefore, we implement the standard two-step estimator developed by Heckman (1979). According to this procedure, in the first stage (selection equation) the probability of participating in an IMF program is estimated by a standard probit regression and in the second stage (outcome equation) the loan size is a linear function of the set of variables plus the inverse Mills ratio calculated from the first-stage regression, which corrects for sample selection bias.

Specifically, in the selection equation the probability that a country obtains a line of credit from the IMF (IMFLOAN) is a function of: 1) a country-specific measure of the intensity of the crisis, 2) indicators of the political and economic connections with the US or G7 countries, 3) some macroeconomic and institutional characteristics which are expected to drive the Fund's lending strategy and governing the relationship between the IMF and the borrower, and 4) a specific set of variables which, since they should exclusively affect the likelihood of getting a loan and not also its amount, are taken as excluding restrictions:

$$
\begin{array}{r}
\operatorname{Pr}(I M F L O A N)=\Phi(C R I S I S, P O L I T I C A L, E C O N O M I C, \\
C O N T R O L S, R E S T R I C T I O N S)
\end{array}
$$

In the outcome equation, the amount of IMF credit over GDP ( $L O A N S I Z E)$ is a linear function of the same variables outlined above, with the exception of that included in RESTRICTIONS and plus the inclusion of a dummy identifying the non-concessional loans, whose size is generally larger (Table 1), and of the inverse Mills ratio estimated in the selection equation $(\hat{\lambda})$ which corrects for the sample selection:

$$
L O A N S I Z E=\alpha+\beta C R I S I S+\sum_{i=1}^{m} \gamma_{i} \operatorname{POLITICAL}_{i}+\sum_{i=1}^{p} \delta_{i} \operatorname{ECONOMIC}_{i}+\sum_{i=1}^{q} \theta_{i} \operatorname{CONTROL} S_{i}+\hat{\lambda}
$$

\subsubsection{The variables}

Following Berkmen et al. (2009), the key variable identifying the severity of the global financial crisis in each country in the medium run is the difference in the cumulated GDP growth over the period 2008-2011, between the April 2008 and October 2009 IMF growth projections as in the World Economic Outlook (CRISIS):

$$
\begin{aligned}
C R I S I S=\{ & {\left[100 \times\left(1+G R O W T H_{2008}^{A p r 08}\right)\right] \times\left(1+G R O W T H_{2009}^{A p r 08}\right) \times\left(1+G R O W T H_{2010}^{A p r 08}\right) \times\left(1+G R O W T H_{2011}^{A p r 08}\right)-} \\
& \left.-\left[100 \times\left(1+G R O W T H_{2008}^{O c t 09}\right)\right] \times\left(1+G R O W T H_{2009}^{O c t 09}\right) \times\left(1+G R O W T H_{2010}^{O c t 09}\right) \times\left(1+G R O W T H_{2011}^{O c t 09}\right)\right\}
\end{aligned}
$$

\footnotetext{
${ }^{11}$ Figures are almost identical considering the median loan arrangement for each facility.
} 
where the subscript refers to the year in question and the superscript to the date of the growth projection ${ }^{12}$. With respect to a simple figure on the actual economic growth rate, the variable $C R I S I S$ has the advantage of being independent of the specific country's initial conditions. For example, it is possible to observe a severe downward revision in the growth estimates but still a positive GDP growth rate in 2009: looking at the latter would provide a misleading indication of the impact of the global crisis per se, it being affected also by the general economic condition of the country ${ }^{13}$. In addition, CRISIS takes into account the medium-term impact of the crisis. Yet, one could argue that CRISIS is not independent of the IMF lending policy. In particular, to the extent that the IMF needs to validate their intervention in a country with the constituency members, it may have an interest to give to countries wishing to support lower growth forecasts. However, empirical studies on the IMF's forecast accuracy indicates that there is a tendency to overpredict real GDP growth rate for countries with large loans outstanding from the Fund (Timmermann, 2006; Dreher, Marchesi and Vreeland, 2008), while Mrkaic (2010), extending the analysis to all member states, shows that IMF's real GDP current-period forecasts tend to be unbiased. If the IMF has restricted its role to the traditional one of crisis resolution, CRISIS should not have any significant effect on the participation in and the generosity of a lending program, once controlled for country's economic conditions. By contrast, if concerns of prevention and mitigation of contagion effects have partially driven the IMF lending decisions, the coefficient on CRISIS should be positive and significant in both the selection and outcome equations.

With regard to the political similarity between recipients and the Fund's major shareholders, our preferred measure of foreign policy friendship is the dichotomic indicator proposed by Kilby (2009a), FRIEND, which identifies countries as allies or not with the G7 (US) according to whether they modify their own political orientation to accommodate G7 (US) preferences on important voting issues in the UNGA. The latter tendency is measured as the difference between the alignment score in important votes in the UNGA and the same score in all other UNGA votes $(D I F F E R E N C E)^{14}$. This measure, introduced by Barnebeck Andersen, Harr and Tarp (2006), is consistent with the idea that what may induce the US and G7 administrations to use their influence in the IMF's Executive Board is the degree of concessions that the potential recipient trades off.

To check the robustness of our results, we re-estimate our models by using other indicators of foreign policy proximity suggested in the literature. First, we consider just DIFFERENCE. Second, like Thacker (1999), we consider the change of political preferences over time by calculating the difference between the average alignment score in years $t$ and $t-1$, again for all UNGA votes $\left(C H A N G E^{A L L}\right)$ and for the important ones only $\left(C H A N G E^{I M P}\right)$. Finally, we consider the absolute proximity to IMF major shareholders: (a) the average alignment score in each year, calculated for all votes (PROXIMITY $\left.{ }^{A L L}\right)$ and for important votes only

\footnotetext{
${ }^{12}$ We re-estimate all the models with alternative measures of CRISIS, by using the most recent IMF estimates published in the April 2010 WEO instead of those published in October 2009, and calculating the cumulated growth differential over shorter periods (2008-2009 and 2008-2010). Results are broadly consistent with those reported in Tables 4-8 and are not shown for reasons of space.

${ }^{13}$ Algeria, for example, grew at $3 \%$ in 2008 and had a preliminary growth rate in 2009 higher than $2 \%$, but the cumulated reduction in economic growth in 2008 and 2009 amounts to almost $5 \%$.

${ }^{14}$ We are greatly indebted to Christopher Kilby for having shared his dataset on UN voting data. Refer to Kilby $(2009 b)$ for a detailed description of the dataset, which includes the identification of important votes as declared by the US State Department and, in the updated version used here, some important votes that are not covered in the original Voeten and Merdzanovic (2009) UN data set (previously cited as Voeten 2004). As in Thacker (1999) and Dreher and Jensen (2007), the alignment score of country $Y$ with country $X$ is measured considering, for each vote, that country $Y$ scores 1 if it follows $X, 0.5$ if it abstains or is absent when $X$ votes (or vice versa), and 0 if it opposes $X$. Political similarity with the G7 is built by averaging the pairwise annual alignment scores.
} 
(PROXIMITY $\left.Y^{I M P}\right)$; (b) the affinity of nations index (AFFINITY) introduced by Gartzke (1998), which is computed using the UNGA voting data collected by Voeten and Merdzanovic (2009).

Since it is reasonable to expect Fund assistance to follow political concessions to IMF shareholders with a certain time lag and to reward countries which demonstrate a persistent political closeness instead of a one shot event, all these variables are calculated over a five-year period (2003-2007) before the crisis. Nevertheless, the robustness of our findings has been checked by calculating the political variables over shorter or longer time horizons and just in the year before the lending arrangement.

Other than political friendship, we also consider the possibility that the economic and financial interests of G7 countries affect IMF lending to developing countries. In particular, we include the exposure of industrialized countries' banking system $(B A N K S)$ and the intensity of foreign direct investments $(F D I)$ in developing countries. Foreign investors are likely to be a homogeneous group in the home country, the most able to lobby the government to induce the IMF to provide financial support to destination countries when in trouble (Breen, 2010; Copeletovich, 2010a). However, to the extent that multinational banks and companies choose destination countries also from their macroeconomic stability, the greater the foreign presence, the lower the probability of a crisis and of a Fund program. In this view, it is reasonable to expect that larger foreign direct investments and banks' financial exposure are negatively correlated with the probability of IMF assistance but, once the endogenous selection has been taken into account, drive larger loans ${ }^{15}$.

The set of control variables included in the model was chosen on the ground of the empirical findings of the most relevant literature on IMF lending, and reflects foreign imbalances, the levels of economic development and the relationships with the Fund (Bird, 2007; Steinwand and Stone, 2008; Ghosh et al., 2008). Specifically, we consider the current account balance over GDP $(C A B)$ and an indicator of the level of international reserves in terms of months of imports (RESERVE) as measures of foreign imbalances. As proxies of the country's income and macroeconomic conditions we include, respectively, the real GDP per capita $(G D P P C)$, the rate of inflation (INFLATION) and the real per capita GDP growth (GROWTH). The country's relationship with the Fund is measured by the country's size $(G D P)$, which might force the Fund to intervene to reduce the risk of contagion, by its quota (QUOTA), which is found to positively affect loan size (Barro and Lee, 2005), and by the degree of compliance with conditionality (NON-COMPLIANCE) in the previous lending arrangements (Dreher and Walter, 2010). Limited to the outcome equation, we also control for the general different loan size (relative to GDP) between commercial and concessional loans including a dummy variable identifying SBA, EFF and FCL arrangements $(S B A / E F F / F C L)$.

Finally, we add two variables in the selection equation which should affect the participation in an IMF program, but not the amount of the loan agreed. First, based on a vast literature finding that newly elected governments are more likely to seek the assistance of the Fund than governments at the mid/end of their electoral mandate (Przeworski and Vreeland, 2000; Vreeland, 2003; Sturm, Berger and De Haan, 2005), we include an election dummy for countries which undertake an executive or legislative election in the 18 months prior to the lending arrangement (ELECTIONS). Second, given the specific design of the empirical exercise we also include a dummy variable which identifies countries which already had an IMF lending

\footnotetext{
${ }^{15}$ Much of the literature considers exports to or total trade with IMF member countries as a measure of economic interest. We check the robustness of our findings taking bilateral imports from, and total trade with, G7 as alternative indicators of economic interests. However, given that exporters are less likely than multinational firms to exert their influence on domestic governments, we do not find a significant correlation with either the participation in an IMF loan agreement, or the size of the loan.
} 
arrangement in place at the end of 2007 and for which the likelihood of getting a new loan should be lower $(\text { EXISTING LOAN })^{16}$.

\subsection{Summary statistics}

Due to data availability, equations 1 and 2 are estimated on a sample of 118 low- and middleincome countries, 45 of which signed an IMF agreement over the sample period (IMF LOAN= 1, Table 2). The extent of the crisis has been extremely harsh and widespread for almost the whole sample, with only 14 countries not revising downward their growth projections; specifically the crisis hit hardest in Europe and Central Asia $(C R I S I S=0.20)$, while its consequences are less severe in South Asia, Middle East and Africa. In Table 3 we report the detailed definition of variables used in the analysis, their sources and sample average, conditional on having signed an IMF loan agreement or not. On the whole, it is worth noting that the univariate analysis shows that IMF assistance targets richer countries with more severe foreign imbalances and where the impact of the crisis is greater. As regards the political influence hypothesis, the conditional averages of some political similarity indicators suggest that countries receiving IMF assistance are significantly closer to G7 and US strategic interests than countries which do not participate in a lending program. With respect to the financial and economic interests of Fund large shareholders, we observe that a larger presence of foreign banks and multinationals is associated with a lower frequency of IMF loans, confirming that foreign investment targets less vulnerable countries. Finally, IMF loan agreements were more likely in countries which have recently undertaken elections.

\section{Results: the basic models}

In Table 4 we report the two-step estimates of the empirical model for IMF loan allocation, which we comment on below separately for the variables capturing the macroeconomic health of IMF member states and their politico-institutional weight within the Fund (Section 4.1) and for the key variables concerning the intensity of the crisis and the political-economy interests of G7 countries (Section 4.2). At the outset, however, it is worth noting that in the selection equation both ELECTION and EXISTING LOAN are highly significant with the expected sign, confirming the validity of our exclusion restrictions. In addition, in the outcome equation the coefficient on the estimated inverse Mills ratio is generally negative and statistically significant, suggesting that the selection in the IMF loan arrangement is actually non-random and some unobservables characteristics affecting the likelihood of obtaining a line of credit also influence loan size.

\subsection{Macro-imbalance and institutional indicators}

In the first model (column 1), we assume that the IMF lending policy is responding to the degree of foreign imbalance in LMIC - as in accordance with the original Bretton Woods mandate -, their macroeconomic conditions and their size and institutional weight. Our findings differ in part from those obtained by previous studies, confirming the erratic nature of the IMF lending policy and the specificity of its response to the current global crisis.

\footnotetext{
${ }^{16}$ Since there is evidence of borrowing "recidivism", meaning that countries that have borrowed in the past are more likely to borrow in the future (Barro and Lee, 2005; Sturm, Berger and De Haan, 2005; Atoyan and Conway, 2006), for robustness we also consider a variable measuring the number of years in which an IMF lending arrangement was in place in the decade before the crisis (Dreher, 2006b). Results, not shown for reason of space, are unaffected and this variable is not significant, supporting the specific nature of the crisis and the choice of focusing exclusively on this period.
} 
Starting from the the countries' macroeconomic conditions, we find that balance of payments problems matter for the probability of obtaining a loan, albeit not for its size. Consistent with the major evidence in the literature (Cornelius, 1987; Knight and Santaella, 1997; Vreeland, 2003; Barro and Lee, 2005; Sturm, Berger and De Haan, 2005), a shortage of official reserve significantly increases the likelihood of entering a loan agreement with the Fund. However, we also find that reserve shortage has a negative impact on loan size. Such an odd result can be explained by the exceptional nature of the global crisis, which suggests a prudent stance be maintained in lending decisions. In this view, the IMF, once it has decided to provide financial assistance to countries suffering a shortage of international reserves, appears to favor those countries with a relative abundance of reserves as it indicates a more prudent macroeconomic management by governments in charge and a greater sustainability of the current macroeconomic environment. Similarly, a current account deficit is associated with a higher probability of signing a loan agreement, while it has no significant effect on loan size (Conway, 1994; Santaella, 1996; Sturm, Berger and De Haan, 2005; Eichengreen, Gupta and Mody, 2006; Copeletovich, 2010b).

As regards the economic health of the applicants, we find that in the two-and-a-half years after the starting of the global crisis the IMF has targeted countries with lower rates of GDP growth and, other things being equal, has allocated resources to poorer countries, consistent with a vast literature on IMF lending (Joyce, 1992; Garuda, 2000; Dreher and Vaubel, 2004; Barro and Lee, 2005; Sturm, Berger and De Haan, 2005; Eichengreen, Gupta and Mody, 2006). In addition, we find that countries plagued by high inflation rates were more likely to sign an IMF loan agreement (Bird, 1995; Evrensel, 2005; Biglaiser and DeRouen Jr, 2010), even if this does interfere with the size of the loan.

The variables measuring the quality of institutions in LMICs and their political weight also contribute to explain IMF lending during the crisis. Countries with higher quotas have not experienced a greater probability of participating in a loan agreement with the Fund, but they have received larger loans (Barro and Lee, 2005). Similarly, a sounder record of compliance with conditionality in the past has no significant effect in the selection equation, but is positively associated with $L O A N S I Z E$, suggesting that the Fund rewards better performing recipients. By contrast, the level of GDP, measuring the political-economic size of the applicant member, is generally not significant and sometimes enters the outcome equation with a negative and significant sign. This result is consistent with a lending strategy that, in the wake of the crisis, caps loans for large economies in order to preserve sufficient resources to lend to a vast pool of applicants.

The pervasiveness of corruption practices in the borrowing country has reduced the "generosity" of the IMF support - even if the statistical significance of CORRUPTION in the outcome equation is limited - but has not deterred the Fund from starting lending programs. Such a probability is instead affected by the internal political strength of national governments: we find that governments were more likely to enter a loan agreement if they were in the first 18 months of the electoral mandate, so that the associated stigma can vanish before the new election (Przeworski and Vreeland, 2000; Sturm, Berger and De Haan, 2005).

Finally, as expected, countries with an IMF loan already in place at the end of 2007 are less likely to negotiate a new one ${ }^{17}$. In addition, it is worth noting that the dummy for nonconcessional loans has the expected positive effect on LOAN SIZE only in the basic specification (column 1), while its statistical significance vanishes once CRISIS is included in the model; this result is easily explained by the high correlation between the intensity of the crisis and the

\footnotetext{
${ }^{17}$ Nevertheless, six (Benin, Burkina Faso, Grenada, Republic of Congo, Malawi and Moldova) out of the 20 countries in the sample with a loan arrangement in place at the end of 2007 agreed to a new loan between 2008 and June 2010, consistently with the presence of borrowing "recidivism".
} 
kind of arrangement, since middle-income countries qualifying for non-concessional loans have most suffered the impact of the global recession (CRISIS is equal to $9.4 \%$ in countries with an SBA, EFF or FCL arrangement, and to $6.4 \%$ in PRGF-eligible countries).

\subsection{The intensity of the crisis, political similarity and economic interests}

In models reported in columns 2-6 we add the crisis indicator, the variables capturing the political-economy interests of the G7 in LMICs and the interaction effects between the latter and the intensity of the crisis in such countries. The intensity of the crisis has had no influence on the decision of IMF and member countries to sign a loan program. In this perspective, it would seem that the IMF has not taken on the role of preventing contagion during the global recession. However, CRISIS is significantly associated with the loan size granted to borrowing countries, suggesting that the Fund has supported member countries most affected by the crisis beyond their actual foreign and economic imbalances.

The positive and significant coefficient on FRIEND $D_{G 7}$ in the selection equation in column 3 indicates that foreign policy friendship with G7 countries has made the financial assistance by the Fund more likely. By contrast, being a policy ally of the G7 has had no significant effect on loan size. According to the estimates reported in column 3, the marginal effect of $C R I S I S$ in the outcome equation is 0.21 , so that a country where the crisis caused a downward revision in the IMF growth projections by 5 percentage points more than the average has received a loan whose size is one percent of GDP larger than the average IMF loan. Given the high variability of CRISIS in our sample (the interquantile range is 0.094), this effect is economically relevant, as testified also by the estimated elasticity, equals to 0.47. Equally sizable is the effect of $F R I E N D_{G 7}$ in the selection equation: even controlling for several other factors, member countries voting similarly to G7 administrations in the UNGA have a $25 \%$ higher probability to participate in an IMF loan program.

Further confirmation of the importance of the influence hypothesis comes from FDI and $B A N K S$. Consistent with the idea that multinational enterprises invest in healthy countries but that, when the latter are in trouble, they directly and indirectly lobby international financial institutions to intervene, we find that the probability of signing an agreement with the Fund during the current crisis has been significantly lower for LMICs able to attract investments from abroad. However, for those who actually entered a program, the larger the share of FDI from the G7 over GDP, the greater the support from the Fund. For instance, a shift from the first to the third quartile of the sample distribution of FDI corresponds to a $4 \%$ reduction in the probability of signing a loan agreement (from $27 \%$ to $23 \%$ ), but to an increase in the size of the loan equal to $0.33 \%$ of GDP. Similar results also hold for the direct investments in the financial sector by Western countries. The effect of the exposure of foreign banks on LOAN SIZE for countries selected to participate in an IMF program is twice larger than the one due to $F D I-$ the conditional elasticity being 0.16 -, while it does not influence the likelihood of entering in a program.

This story slightly changes when we include the interaction terms between the severity of the financial crisis and the politico-economic interests of IMF major shareholders. First, the coefficient on $F R I E N D_{G 7}$ is no longer significant in the selection equation, while the interaction $C R I S I S \times F R I E N D_{G 7}$ is positive and statistically significant with a p-value of 0.011 (column 4). This means that the political friendship with the Group of 7 is only a necessary condition to participate in an IMF program, as it also depends on the member state being severely hit by the global crisis. The coefficient on the interaction term can also be interpreted as evidence that the IMF acted to mitigate the contagion effect, targeting the G7-friend countries most exposed to the global crisis. For example, a G7-friend country which does not experience any downward 
revision in GDP growth has an estimated probability of obtaining an IMF loan equal to 15\%, while if the same country faces a $20 \%$ cumulated reduction in the estimated GDP growth over 2008-2011, its probability of securing a loan rises to $36 \%^{18}$. However, once controlled for the selection, the IMF capacity to allocate more funds to countries more affected by the crisis remains valid, regardless of the borrower's political proximity to G7 countries.

Second, the inclusion of the interplay between CRISIS and BANKS (model 5) confirms that both the gravity of the crisis and the exposure of foreign banks in LIMCs have played no role in the probability of the latter entering a loan agreement, but also shows that the IMF response to the crisis has been less sizable where foreign banks are particularly exposed. The negative coefficient on $C R I S I S \times B A N K S$ could appear counter-intuitive, since we would expect G7 governments to press the IMF to extend larger loans if their banks were exposed towards countries experiencing severe downturns. However, at a time of global crisis, the Fund seems to have considered the exposure of foreign banks in the borrowing country as an additional source of instability advising against substantial involvement in its rescue. By contrast, the influence of multinational enterprises is not differentiated according to the magnitude of the economic crisis, even if the negative selection effect appears to materialize only in countries suffering the most from the global crisis $^{19}$.

\section{Results: robustness}

To check the validity of our findings we undertake a number of robustness exercises. First, we inspect the validity of the IMF politicization hypothesis considering other candidate indicators of foreign policy proximity between the applicant country and the G7 or US (Section 5.1). Then we verify the robustness of the empirical model by including additional controls (Section 5.2) and excluding from the sample the former Soviet republics (Section 5.3).

\subsection{Alternative indicators of political similarity}

Up to now, we have assumed the G7 as the group of countries that has the power to influence the IMF's choices and we have taken the dummy FRIEND as the measure of political similarity. Actually, the G7 expresses all the five appointed members on the Executive Board and "a subgrouping of G-7 Finance Ministry deputies regularly convenes to discuss the issues confronting the organization and the world economy $[\ldots]$. It is this group [...] which guides the institution [... and] assumes the strategic guiding role in respect of the IMF" (Woods, 2006, p.191). Nevertheless, inside the Group of 7 the US has a leading position. The quota they contribute to the Fund gives them a veto power on all important decisions. In addition, the close relations between the Fund and US Treasury staff and the over-representation of US-trained economists within the Fund give the US a power than goes far beyond their official role (Woods, 2003). Whoever is the influential shareholder, the literature on IMF has suggested several different measures for the political similarity between countries (Section 2).

In Tables 5 and 6 we show the results of different measures of political similarity between the candidate country and the G7 and US respectively. Since the coefficients of control variables are very stable across different model specifications and mirror those already discussed, we report exclusively the coefficients on the key variables.

\footnotetext{
${ }^{18}$ The variation considered in the example roughly corresponds to a shift from the first to the ninth decile of the sample distribution of CRISIS.

${ }^{19}$ The coefficient on $C R I S I S \times F D I$ in the selection equation has a p-value of 0.103 and implies that the impact of FDI on the probability of getting a loan is negative as long as CRISIS $>0.06$.
} 
On the whole, our results suggest that: 1) foreign policy similarity matters for the selection in the loan arrangement, but not for the loan size, and 2) the alignment with the G7 matters more than just merely being an ally of the US. In fact, when considering the relationship with the G7 countries, we find that the static alignment measure $\left(P R O X I M I T Y_{G 7}\right)$, its change over time $\left(C H A N G E_{G 7}\right)$ and the country's deviation from its political orientation to accommodate the G7 political preferences on important votes (DIFFERENCE $E_{G 7}$ ), are all positively correlated with the probability of signing a loan agreement with the Fund. The same does not apply when limiting the analysis to the US, for which the proposed measures are not particularly robust. This result can be explained by multilateralism becoming more important in times of crisis and also by the fact that the global turmoil coincided with a shift from US geopolitical dominance to a multipolar international framework (Dickinson, 2009; Copeletovich, 2010a).

\subsection{Additional controls}

In Table 7 we add further controls on the basic specification, which part of the literature finds to significantly affect IMF lending strategies. In column 1, we consider a dummy identifying the countries which sat as Temporary Members of the UN Security Council over 2005-07 (UNSC), finding a positive effect on the likelihood of entering a loan agreement. This result is in line with the evidence discussed by Dreher, Sturm and Vreeland (2009b), who document the existence of a clear pattern of votes trade inside international organizations, with developing countries using their temporary seat in the United Nations Security Council (UNSC) to vote along with the US in order to gain favorable economic treatment from the IMF.

In column 2 we include the amount of bilateral aid (over GDP) provided by G7 countries $(A I D)$. Bilateral foreign assistance is widely used by donors as a foreign policy instrument responding to their strategic interests in the recipient country (Alesina and Dollar, 2000) and can be expected to have a catalytic effect on IMF lending. Results, however, show a slightly significant and negative correlation between the amount of foreign bilateral assistance and the participation in an IMF loan agreement. Therefore, in times of crisis and shrinking aid budgets, there is a sort of substitution effect between bilateral and multilateral assistance, with the IMF targeting countries where donors' exposure was relatively smaller.

We then control for the possibility that the IMF rewards more open and globalized countries, because of their closeness to the "Washington Consensus" prescriptions. In this way, we also control for the possibility that bilateral FDI from the G7 merely accounts for the country's degree of openness. In column 3 we consider a standard measure of openness (imports plus exports over GDP, OPENNESS), while in column 4 we measure the degree of globalization by the KOF index of globalization (GLOBALIZATION), which is build by aggregating several variables, including actual trade and capital flows, tariffs, capital account restrictions and measures of political integration in the world economy (Dreher, 2006a). In both cases there is no evidence that, during the crisis, the Fund has allocated its resources according to the countries' degree of integration in the global economy, while the coefficient on FDI is unaffected.

In columns 5 and 6 we include total debt service as a share of national GDP (TDS) and the ratio of public external debt over GDP $(D E B T)$ as further indicators of foreign imbalances. Results do not show any significant effect, consistent with the ambiguous effect external debt has on participation in a lending program ${ }^{20}$.

\footnotetext{
${ }^{20} \mathrm{By}$ causing balance of payments and financial stability problems, a large external debt induces both the country and the IMF to sign an arrangement (Sturm, Berger and De Haan, 2005; Eichengreen, Gupta and Mody, 2006; Przeworski and Vreeland, 2000; Dreher, 2006b; Stone, 2008). However, by producing concerns on the creditworthiness of the applicant country, it also reduces the IMF's willingness to support the financial requests of highly indebted member states (Bird and Rowlands, 2001; Oatley and Yackee, 2000; Przeworski and Vreeland, 2000; Broz and Hawes, 2000; Dreher, 2006b; Stone, 2008).
} 
Finally, in columns 7 we include a variable accounting for the presence of a democratic regime (DEMOCRACY). Theoretically, the IMF can be interested in supporting (young) democratic regimes, but it could also be interested in favoring the transition of autocratic regimes to democracy or to be worried by the capacity of unstable democracies to credibly pursue drastic adjustment programs. At the same time, autocratic governments are less concerned with the popularity of their economic policy decisions and therefore may be more likely to turn to the Fund but are also less interested in using the IMF as a scapegoat to launch macroeconomic adjustment programs ${ }^{21}$. Our results do not help distinguish between these competing theories as we find no significant correlation between the two phenomena (Thacker, 1999).

\subsection{Former Soviet republics}

Former Soviet republics are at the center of large geopolitical and economic interests, mainly related to the provisions of natural resources but also to Russia's resurgence and the stability of international relations (Larrabee, 2010). Some authors have argued that the response of the IMF to the crisis was biased towards Eastern European countries in order to accommodate the economic interests of Western Europe (Stiglitz, 2010). For example, the IMF position with Ukraine mimics the foreign policy response of the US and Europe to Ukrainian domestic affairs: after the brief enthusiasm following the 2004 election, the IMF involvement in Ukraine plummeted as soon as the Orange Revolution's rhetoric of NATO membership, European integration and governance reform failed to live up with reality (Karatnycky, 2010). Thus, the huge USD 16.4 billion loan disbursed by the Fund in November 2008 to support the incumbent Ukrainian government to deal with the crisis has been interpreted as a by-product of US-backing to Kiev and of the renewed Ukraine's targets of EU and NATO membership and integration into the global economy, as testified by the WTO membership agreed in May $2008^{22}$. In a similar vein, after the South-Ossetia conflict in August 2008, Washington condemned the Russian military response and reasserted its strategic interest in the region also by exerting influence on the IMF, which actually signed a SBA with Georgia in September $2008^{23}$.

Therefore, given the large interests at stake and the relevance of some of the agreements signed by the IMF with former Soviet republics, it is worth assessing whether the political influence hypothesis survives as long as those countries are excluded by the sample. Results are reported in Table 8 and they largely support previous findings. Dropping some of the countries where the crisis was particularly severe and the response on the Fund extremely generous reduces the economic magnitude but does not wipe out the significance of the coefficient on CRISIS in the outcome equation. On the whole, the positive and significant coefficients on CRISIS, $B A N K S$ and $F D I$ in the outcome equation and on $F R I E N D_{G 7}$ in the selection equation confirm that, also in the restricted sample, the response of the IMF to the crisis was driven by recipients' economic needs and by the economic interests of and the political similarity with the

\footnotetext{
${ }^{21}$ Such theoretical ambiguity is reflected in the empirical findings: Edwards and Santaella (1993) and Harrigan, Wang and El-Said (2006) report a positive effect of the country's degree of democracy on the participation in IMF programs, while Dreher and Vaubel (2004) and Dreher (2006b) show that IMF loans are more likely to be granted and greater in size in autocratic regimes.

${ }^{22}$ The strategic importance of the area for the provision of natural resources can be seen by the fact that other commentators suggest that the "generous USD 15 billion IMF package [...] was a prize Ukraine won from America for giving up its supply of enriched uranium" (The Economist, 2010).

${ }^{23}$ As the Wall Street Journal wrote in September 2008: "When Russia sent troops into Georgia last month, the West balked at joining the fight. But now that the shooting has ended, Western nations are mobilizing to thwart a key Russian war aim: regime change in Tbilisi. Their weapon is cash. The International Monetary Fund is set to reach a preliminary deal this week that will throw the former Soviet republic a $\$ 750$ million credit line [...]. Both the U.S. and Europe are also working on big assistance packages that Georgia hopes will provide \$2 billion or more" (Higgins, 2008).
} 
IMF shareholders. Finally, it is worth noting that also in this case there is a mutual effect of the intensity of the crisis and of foreign policy friendship: only countries which showed a shift towards the G7 positions are more likely to get a loan, with this probability increasing as the economic impact of the crisis becomes harsher (column 4). By contrast, the interaction between $C R I S I S$ and BANKS is no longer significant: the former Soviet republics drive the negative interaction term reported in Table 4, since they are severely hit by the downturn (on average, $C R I S I S=0.21$, while the corresponding value for the restricted sample is 0.09), but foreign banks' claims account for less than elsewhere (25\% of GDP rather that $30 \%$ ).

\section{Concluding remarks}

After an extensive review of the activity and the World Bank and the IMF, Woods (2006) concludes that the work of the sister institutions "is affected by the preference of their most powerful members, by their own bureaucratic motives, and by politics within countries with whom they work". In this paper we focused exclusively on the Fund and we exploited the 2007-2010 global financial crisis to provide an additional test of the previous proposition. Specifically, building on a large literature arguing that IMF lending is driven by the political similarity between its main shareholders and borrower countries, we sought to assess whether also the response to the crisis was politically driven or the Fund was instead able to target its resources in an economicallyefficient way to the countries most affected by the financial crisis, playing a stabilizing role in the global economy. The intensity of the global downturn, requiring an exceptional reaction, and the IMF recent (ongoing) process of reform are two elements which make this sort of analysis worth doing. Moreover, focusing on a specific event, the global crisis, avoids blending together several different experiences, which generally flaws the empirical assessment of the determinants of IMF lending. On the whole, our results lend some novelty, even if they still provide evidence to support the critics of the IMF. On the one hand, the evidence on the post-2007 loan agreements shows that the political influence hypothesis cannot be discarded. Besides, there are additional findings suggesting that Western donors exert their influence on the Fund to allocate money toward countries where their multinationals and financial systems are more exposed. On the other hand, the loan allocation was consistent with some of the standard macroeconomic variables which should drive IMF lending and, more important, the Fund partially played a stabilization role and channeled more resources where the economic downturn was more severe than expected. Whether this resurgence of economics within IMF lending is either an exceptional response to the crisis, or the first signal of a change in its strategy is a matter for future research.

\section{References}

Alesina, Alberto and David Dollar. 2000. "Who Gives Foreign Aid to Whom and Why?" Journal of Economic Growth 5(1):33-63.

Atoyan, Ruben and Patrick Conway. 2006. "Evaluating the impact of IMF programs: A comparison of matching and instrumental-variable estimators." Review of International Organizations $1(2): 99-124$.

Barnebeck Andersen, Thomas, Thomas Harr and Finn Tarp. 2006. "On US Politics and IMF Lending." European Economic Review 50(7):1843-1862.

Barro, Robert J. and Jong-Wha Lee. 2005. "IMF programs: Who is chosen and what are the effects?" Journal of Monetary Economics 52(7):1245-1269. 
Beck, Thorsten, George Clarke, Alberto Groff, Philip Keefer and Patrick Walsh. 2001. "New Tools in Comparative Political Economy: The Database of Political Institutions." The World Bank Economic Review 15(1):165-176.

Berkmen, Pelin, Robert Rennhack, James P. Walsh and Gaston Gelos. 2009. The Global Financial Crisis: Explaining Cross-Country Differences in the Output Impact. IMF Working Papers 09/280 International Monetary Fund.

Biglaiser, Glen and Karl DeRouen Jr. 2010. "The effects of IMF programs on U.S. direct investment in the developing world." Review of International Organizations 5:73-95.

Bird, Graham. 1995. IMF Lending to Developing Countries. Issues and Evidence. London: Routledge.

Bird, Graham. 2007. "The IMF: A Bird'S Eye View of Its Role and Operations." Journal of Economic Surveys 21(4):683-745.

Bird, Graham and Dane Rowlands. 2001. "IMF Lending: How Is It Affected by Economic, Political, and Institutional Factors?" Journal of Policy Reform 4(2):243-270.

Bird, Graham and Dane Rowlands. 2009. "A disaggregated empirical analysis of the determinants of IMF arrangements: Does one model fit all?" Journal of International Development 21(7):915-931.

Bird, Graham and Dane Rowlands. 2010. "The episodic and unpredictable nature of IMF lending: lessons for policy." The World Economy 33(10):1280-1301.

Bird, Graham and Timothy Orme. 1981. "An analysis of drawings on the International Monetary Fund by developing countries." World Development 9(6):563-568.

Breen, Michael. 2010. Domestic Interests, International Bargaining, and IMF Lending. Working Paper in International Studies 07/2010 Centre for International Studies, Dublin City University.

Broz, Lawrence and Michael Brewster Hawes. 2000. U.S. Domestic Politics and International Monetary Fund Policy. In Delegation and Agency in International Organizations, ed. Darren G. Hawkins, David A. Lake, Daniel L. Nielson and Michael J. Tierney. Cambridge: Cambridge University Press.

Central Intelligence Agency. 2009. The World Factbook 2009. https://www.cia.gov/library/publications/the-world-factbook/index.html Washington DC: Central Intelligence Agency.

Cheibub, José, Jennifer Gandhi and James Vreeland. 2010. "Democracy and dictatorship revisited." Public Choice 143(1):67-101.

Conway, Patrick. 1994. "IMF Lending Programs: Participation and Impact." Journal of Development Economics 45(2):365-391.

Copeletovich, Mark S. 2010a. The International Monetary Fund in the Global Economy. Cambridge: Cambridge University Press.

Copeletovich, Mark S. 2010b. "Master or Servant? Common Agency and the Political Economy of IMF Lending." International Studies Quarterly 54(1):49-77. 
Cornelius, Peter. 1987. "The demand for IMF credits by Sub-Saharan African countries." Economics Letters 23(1):99-102.

Dickinson, Elizabeth. 2009. "New Order. How "the multipolar world" came to be." Foreign Policy .

Dreher, Axel. 2006a. "Does globalization affect growth? Evidence from a new index of globalization." Applied Economics 2009(10):1091-1110.

Dreher, Axel. 2006b. "IMF and economic growth: The effects of programs, loans, and compliance with conditionality." World Development 34(5):769-788.

Dreher, Axel, Jan-Egbert Sturm and James Raymond Vreeland. 2009a. "Development aid and international politics: Does membership on the UN Security Council influence World Bank decisions?" Journal of Development Economics 88(1):1-18.

Dreher, Axel, Jan-Egbert Sturm and James Raymond Vreeland. 2009b. "Global horse trading: IMF loans for votes in the United NationsSecurity Council." European Economic Review $53(7): 742-757$.

Dreher, Axel and Nathan M. Jensen. 2007. "Independent actor or agent? An empirical analysis of the impact of the US interests on IMF conditions." Journal of Law and Economics 50(1):105-124.

Dreher, Axel, Noel Gaston and Pim Martens. 2008. Measuring Globalization - Gauging Its Consequences. New York: Springer.

Dreher, Axel and Roland Vaubel. 2004. "Do IMF and IBRD Cause Moral Hazard and Political Business Cycles? Evidence from Panel Data." Open Economies Review 15(1):5-22.

Dreher, Axel, Silvia Marchesi and James Raymond Vreeland. 2008. "The political economy of IMF forecasts." Public Choice 137(1-2):145-171.

Dreher, Axel and Stefanie Walter. 2010. "Does the IMF Help or Hurt? The Effect of IMF programs on the likelihood and outcome of currency crises." World Development 38(1):1-18.

Edwards, Sebastian and Julio Santaella. 1993. Devaluation Controversies in the Developing Countries: Lessons from the Bretton Woods Era. In A Retrospective on the Bretton Woods System: Lessons for International Monetary Reform, ed. Michael Bordo and Barry Eichengreen. NBER Chapters National Bureau of Economic Research, Inc pp. 405-460.

Eichengreen, Barry J., Poonam Gupta and Ashoka Mody. 2006. Sudden Stops and IMFSupported Programs. IMF Working Papers 06/101 International Monetary Fund.

Evrensel, Ayse. 2005. "IMF Programmes in Emerging Countries." Comparative Economic Studies 47(1):4-22.

Fratianni, Michele and John Pattison. 2005. Who is running the IMF? Critical shareholders or the staff? In Multidisciplinary economics: the birth of a new economics faculty in the Netherlands, ed. P de Gijsel and H. Schenk. Berlin: Springer pp. 279-292.

Gartzke, Erik. 1998. "Kant We All Just Get Along? Opportunity, Willingness, and the Origins of the Democratic Peace." American Journal of Political Science 42(1):1-27. 
Garuda, Gopal. 2000. "The Distributional Effects of IMF Programs: A Cross-Country Analysis." World Development 28(6):1031-1051.

General Accounting Office. 2001. International Monetary Fund. Efforts to AdvanceU.S. Policies at the Fund. Technical report US General Accounting Office.

Ghosh, Atish, Manuela Goretti, Bikas Joshi, Alun Thomas and Juan Zalduendo. 2008. "Modeling Aggregate Use of IMF Resources - Analytical Approaches and Medium-Term Projections." IMF Staff Papers 55(1):1-49.

Harrigan, Jane, Chengang Wang and Hamed El-Said. 2006. "The Economic and Political Determinants of IMF and World Bank Lending in the Middle East and North Africa." World Development 34(2):247-270.

Heckman, James J. 1979. "Sample Selection Bias as a Specification Error." Econometrica 47(1):153-61.

Higgins, Andrew. 2008. "In Rebuff to Russia, IMF Is Set to Lend Georgia USD 750 Million." Wall Street Journal.

International Monetary Fund. 2009. The Implication of the Global Financial Crisis for LowIncome Countries. Washington DC: International Monetary Fund.

International Monetary Fund. 2010. The Funds Mandate - The Future Financing Role - Reform Proposals. Staff paper International Monetary Fund.

Joyce, Joseph P. 1992. "The economic characteristics of IMF program countries." Economics Letters 38(2):237-242.

Joyce, Joseph P. 2006. "Promises Made, Promises Broken: A Model Of IMF Program Implementation." Economics and Politics 18(3):339-365.

Karatnycky, Adrian. 2010. "Orange Peels - Ukraine After the Revolution." The American Interest.

Kaufmann, Daniel, Aart Kraay and Massimo Mastruzzi. 2009. Governance Matters VIII : Aggregate and Individual Governance Indicators, 1996-2008. Policy Research Working Paper Series 4978 The World Bank.

Kilby, Christopher. 2009a. Donor influence in international financial institutions: Deciphering what alignment measures measure. Villanova School of Business Department of Economics and Statistics Working Paper Series 8 Villanova School of Business Department of Economics and Statistics.

Kilby, Cristopher. 2009b. "The political economy of conditionality: An empirical analysis of World Bank loan disbursements." Journal of Development Economics 89(1):310-329.

Knight, Malcom and Julio A. Santaella. 1997. "Economic determinants of IMF financial arrangements." Journal of Development Economics 54(2):405-436.

Larrabee, Stephen F. 2010. "Rethinking Russia: Russia, Ukraine and Central Europe: The Return of Gepolitics." Journal of International Affairs 63(2):33-52.

Meltzer, Allan H. 2010. "The IMF Returns." Review of International Organization forthcoming. 
Mrkaic, Mico. 2010. Data Dissemination Standards and the Statistical Quality of the IMFs World Economic Outlook Forecasts. Working Paper 203 International Monetary Fund.

Oatley, Thomas and Jason Yackee. 2000. "Political Determinants of Balnce of Payments Lending: The Curse of Carabosse?" Available via the internet at: www.unc.edu/ toatley/imf.pdf.

Oatley, Thomas and Jason Yackee. 2004. "American Interests and IMF Lending." International Politics 41(3):415-29.

Payer, Cheryl. 1974. The Debt Trap: The International Monetary Fund and the Third World. Harmondsworth: Penguin.

Pop-Eleches, Grigore. 2008. "Crisis in the Eye of the Beholder. Economic Crisis and Partisan Politics in Latin American and East European International Monetary Fund Programs." Comparative Political Studies 41(9):1179-1211.

Przeworski, Adam and James Raymond Vreeland. 2000. "The effect of IMF programs on economic growth." Journal of Development Economics 62(2):385-421.

Sachs, Jeffrey D. 2004. "How to Run the International Monetary Fund." Foreign Policy (143):60-64.

Santaella, Julio. 1996. "Stylized Facts Before IMF-Supported Macroeconomic Adjustment." IMF Staff Papers 43(3):502-544.

Steinwand, Martin C. and Randall W. Stone. 2008. "The International Monetary Fund: A review of the recent evidence." Review of International Organization 3(2):123-149.

Stiglitz, Joseph E. 2002. Globalization and Its Discontents. New York: W. W. Norton \& Company.

Stiglitz, Joseph E. 2010. Freefall - Free Markets and the Sinking of the Global Economy. London: Allen Lane.

Stone, Randall W. 2008. "The Scope of IMF Conditionality." International Organization 62(4):589-629.

Strauss-Kahn, Dominique. 2009. "The Impact of the Financial Crisis on Low-Income Countries." The Brookings Institution, Washington DC, available via the internet at: http : //www.brookings.edu//media/Files/events/2009/0303 ${ }_{i} m f / 20090303_{i} m f . p d f$.

Sturm, Jan-Egbert, Helge Berger and Jakob De Haan. 2005. "Which variables explain decisions on IMF credit? An extreme bounds analysis." Economics $\&$ Politics 17(2):177-213.

Thacker, Strom Cronan. 1999. "The High Politics of IMF Lending." World Politics 52(10):3875 .

The Economist. 2010. "Viktor ludorum." September 18th.

Timmermann, Mico. 2006. An Evaluation of the World Economic Outlook Forecasts. Working Paper 59 International Monetary Fund.

van Houtven, Leo. 2002. Governance of the International Monetary Fund (IMF) : Decision Making, Institutional Oversight, Transparency and Accountability. Pamphlet Series 53 International Monetary Fund. 
Vaubel, R. 1986. "A public choice approach to international organizations." Public Choice $51(1): 39-57$.

Vaubel, Roland. 1991. The Political Economy of the IMF: A Public Choice Analysis. In The Political Economy of International Organizations: A Public Choice Approach, ed. Roland Vaubel and Thomas D. Willett. Boulder: Westview Press.

Voeten, Erik and Adis Merdzanovic. 2009. "United Nations General Assembly Voting Data." http://hdl.handle.net/1902.1/12379 UNF:3:Hpf6qOkDdzzvXF9m66yLTg== V1 [Version].

Vreeland, James Raymond. 2003. "Why Do Governments and the IMF Enter into Agreements? Statistically Selected CasesInternational Political Science Review." World Economy 24(3):321-343.

Woods, Ngaire. 2003. The United States and the International Financial Institutions: Power and Influence Within the World Bank and the IMF. In US Hegemony and International Organizations, ed. Rosemary Foot, Neil MacFarlane and Michael Mastanduno. Oxford University Press chapter 5 .

Woods, Ngaire. 2006. The Globalizers: The IMF, the World Bank, and Their Borrowers. Ithaca: Cornell University Press.

World Bank. 2009. "Protecting Progress: The Challenge Facing Low-Income Countries in the Global Recession." September. 


\section{A Tables}

Table 1: IMF lending arrangements to LMICs: Jan. 2008 - Jun 2010 (thousands of USD)

\begin{tabular}{|c|c|c|c|c|c|c|c|}
\hline \multicolumn{4}{|c|}{ Nonconcessional loans } & \multicolumn{4}{|c|}{ Concessional loans } \\
\hline Country & $\begin{array}{l}\text { Date of ar- } \\
\text { rangement }\end{array}$ & $\begin{array}{l}\text { Amount of the } \\
\text { loan (USD) }\end{array}$ & $\begin{array}{l}\text { as a share } \\
\text { of GDP }\end{array}$ & Country & $\begin{array}{l}\text { Date of ar- } \\
\text { rangement }\end{array}$ & $\begin{array}{l}\text { Amount of the } \\
\text { loan (USD) }\end{array}$ & $\begin{array}{c}\text { as a share } \\
\text { of GDP }\end{array}$ \\
\hline \multicolumn{4}{|c|}{ Stand-By Arrangements (SBA) } & \multicolumn{4}{|c|}{ Extended Credit Facility (ECF) } \\
\hline Honduras & Apr 2008 & 58,995 & $0.4 \%$ & Togo & Apr 2008 & 144,882 & $5.0 \%$ \\
\hline Georgia & Sep 2008 & $1,134,486$ & $8.8 \%$ & Mali & May 2008 & 42,503 & $0.5 \%$ \\
\hline Pakistan & Nov 2008 & $10,987,859$ & $6.7 \%$ & Zambia & Jun 2008 & 334,219 & $2.3 \%$ \\
\hline Seychelles & Nov 2008 & 56,793 & $6.9 \%$ & Niger & Jun 2008 & 34,972 & $0.7 \%$ \\
\hline Ukraine & Nov 2008 & $31,888,920$ & $17.8 \%$ & Burundi & Jul 2008 & 70,156 & $6.4 \%$ \\
\hline Latvia & Dec 2008 & $2,310,620$ & $6.8 \%$ & Djibouti & Sep 2008 & 19,316 & $2.0 \%$ \\
\hline Serbia & Jan 2009 & $3,977,186$ & $7.9 \%$ & Rep. of Congo & Dec 2008 & 12,847 & $0.1 \%$ \\
\hline El Salvador & Jan 2009 & $1,560,735$ & $7.1 \%$ & São Tomé \& Príncipe & Mar 2009 & 3,933 & $2.2 \%$ \\
\hline Belarus & Jan 2009 & $3,446,307$ & $5.7 \%$ & Côte d'Ivoire & Mar 2009 & 567,896 & $2.4 \%$ \\
\hline Armenia & Mar 2009 & $1,215,423$ & $10.2 \%$ & Tajikistan & Apr 2009 & 158,533 & $3.1 \%$ \\
\hline Mongolia & Apr 2009 & 232,789 & $4.4 \%$ & Ghana & Jul 2009 & 588,351 & $3.5 \%$ \\
\hline Costa Rica & Apr 2009 & 747,567 & $2.5 \%$ & Comoros & Sep 2009 & 20,611 & $3.9 \%$ \\
\hline Guatemala & Apr 2009 & 957,579 & $2.5 \%$ & Congo, DR & Dec 2009 & 526,091 & $4.5 \%$ \\
\hline Romania & May 2009 & $17,376,424$ & $8.7 \%$ & Mauritania & Mar 2010 & 117,351 & $3.7 \%$ \\
\hline Sri Lanka & Jul 2009 & $2,511,025$ & $6.3 \%$ & Grenada & Apr 2010 & 13,325 & $2.0 \%$ \\
\hline Bosnia \& Herz. & Jul 2009 & $1,540,690$ & $8.3 \%$ & Guinea-Bissau & May 2010 & 33,962 & $7.4 \%$ \\
\hline Angola & Nov 2009 & $1,304,257$ & $1.5 \%$ & Benin & Jun 2010 & 112,796 & $1.7 \%$ \\
\hline Dominican Rep. & Nov 2009 & $1,662,020$ & $3.7 \%$ & Burkina Faso & Jun 2010 & 70,086 & $0.9 \%$ \\
\hline Maldives & Dec 2009 & 87,163 & $6.9 \%$ & Lesotho & Jun 2010 & 63,596 & $3.9 \%$ \\
\hline Jamaica & Feb 2010 & $1,245,946$ & $8.9 \%$ & Total & & $2,935,424$ & $2.4 \%$ \\
\hline Iraq & Feb 2010 & $3,609,218$ & $3.9 \%$ & \multicolumn{4}{|c|}{ Exogenous Shocks Facility - (ESF) } \\
\hline \multirow{2}{*}{ Total } & \multirow{2}{*}{\multicolumn{3}{|c|}{$\begin{array}{c}87,912,001 \\
\text { Extended Arrangements (EFF) }\end{array}$}} & Malawi & Dec 2008 & 158,078 & $3.7 \%$ \\
\hline & & & & Kyrgyz Republic & Dec 2008 & 101,133 & $2.0 \%$ \\
\hline \multirow[t]{3}{*}{ Moldova } & Jan 2010 & 561,245 & $9.3 \%$ & Senegal & Dec 2008 & 184,272 & $1.4 \%$ \\
\hline & & & & Tanzania & May 2009 & 332,237 & $1.6 \%$ \\
\hline & lexible Cred & Line $(F C L)$ & & Mozambique & Jun 2009 & 172,504 & $1.7 \%$ \\
\hline Mexico & Apr 2009 & $95,751,800$ & $8.8 \%$ & Ethiopia & Aug 2009 & 233,480 & $0.9 \%$ \\
\hline Poland & May 2009 & $41,577,076$ & $7.9 \%$ & Total & & $1,181,705$ & $1.5 \%$ \\
\hline Colombia & May 2009 & $14,104,014$ & $5.9 \%$ & \multicolumn{4}{|c|}{ Standby Credit Facility (SCF) } \\
\hline Total & & $151,432,890$ & $8.2 \%$ & Solomon Islands & Jun 2010 & 18,951 & $3.0 \%$ \\
\hline
\end{tabular}

Notes: Elaborations on IMF data, as of June 30, 2010. Original data in SDR are converted into USD at the June 30, 2010 official exchange rate (1.5185). Countries which signed more than one arrangement in the sample period (El Salvador, Seychelles, Armenia, Mexico, Colombia, Poland, Liberia, Moldova, Armenia, Malawi and Maldives) are considered as single observations. Liberia is excluded as an outlier. The size of the loan agreed is the sum of the amounts agreed in each separate loan. The lending facility and the date of arrangement of the largest loan are taken as references for the lending arrangement. The ratio of the amount agreed over GDP is calculated with reference the 2008 GDP. 


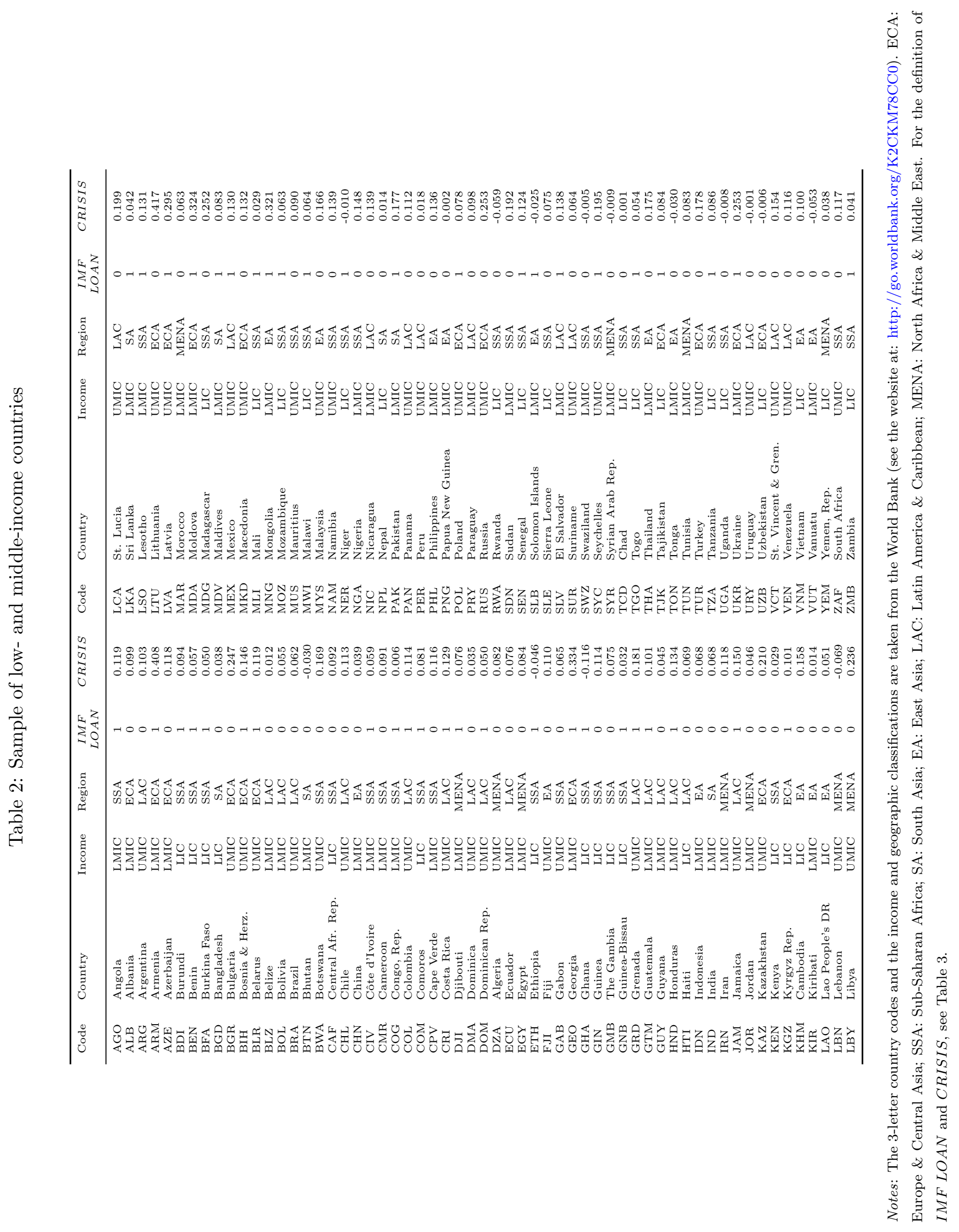


Table 3: Variables: description, sources and sample means by participation in IMF programs.

\begin{tabular}{|c|c|c|c|}
\hline \multirow[t]{3}{*}{ VARIABLE } & \multirow[b]{3}{*}{ Dependent variables } & \multicolumn{2}{|c|}{ SAMPLE MEANS } \\
\hline & & \multicolumn{2}{|c|}{$\begin{array}{ll}\text { IMF pro- } & \text { No pro- } \\
\text { gram } & \text { gram }\end{array}$} \\
\hline & & & \\
\hline$I M F L O A N$ & $\begin{array}{l}\text { Country with a loan in place: dummy equal to one if the country } \\
\text { agreed on an IMF loan between Jan } 2008 \text { and Jun 2010, and zero } \\
\text { otherwise. Source: IMF }\end{array}$ & \multicolumn{2}{|c|}{ Whole sample: 0.381} \\
\hline$L O A N S I Z E$ & $\begin{array}{l}\text { Loan size: amount of IMF credit agreed (\% } 2008 \text { GDP). Source: } \\
\text { IMF }\end{array}$ & 0.046 & n.a. \\
\hline \multicolumn{4}{|c|}{ Crisis variable } \\
\hline CRISIS & $\begin{array}{l}\text { Extent of the crisis, measured as the difference in the cumulated } \\
\text { GDP growth over the period 2008-2011, between the April } 2008 \\
\text { and October } 2009 \text { estimates. Source: WEO database (October } \\
2009 \text { and April 2008) } \\
\text { Political similarity variables }\end{array}$ & 0.112 & $0.089 *$ \\
\hline$F R I E N D_{G 7}$ & $\begin{array}{l}\text { Dummy equal to one if the share of alignment votes with G7 } \\
\text { countries on important UNGA votes is greater than that on all } \\
\text { other UNGA votes. Source: Kilby }(2009 b)\end{array}$ & 0.933 & $0.794^{* *}$ \\
\hline$F R I E N D_{U S}$ & $\begin{array}{l}\text { Dummy equal to one if the share of alignment votes with the US } \\
\text { on important UNGA votes is greater than that on all other UNGA } \\
\text { votes. Source: Kilby }(2009 b)\end{array}$ & 0.467 & 0.356 \\
\hline$D I F F E R E N C E_{G 7}$ & $\begin{array}{l}\text { Difference between the share of alignment votes with G7 countries } \\
\text { on important UNGA votes and on all other UNGA votes. Source: } \\
\text { Kilby }(2009 b)\end{array}$ & -0.011 & -0.032 \\
\hline DIFFERENCE $E_{U S}$ & $\begin{array}{l}\text { Difference between the share of alignment votes with the US on } \\
\text { important UNGA votes and on all other UNGA votes. Source: } \\
\text { Kilby }(2009 b)\end{array}$ & 0.117 & $0.090 *$ \\
\hline$C H A N G E_{G 7}^{A L L}$ & $\begin{array}{l}\text { Change in the share of alignment votes with G7 countries on reg- } \\
\text { ular UNGA votes between years t and t-1. Source: Kilby }(2009 b)\end{array}$ & -0.005 & $-0.008^{* *}$ \\
\hline$C H A N G E_{U S}^{A L L}$ & $\begin{array}{l}\text { Change in the share of alignment votes with the US on regular } \\
\text { UNGA votes between years t and t- } 1 \text {. Source: Kilby }(2009 b)\end{array}$ & -0.013 & -0.013 \\
\hline$C H A N G E_{G 7}^{I M P}$ & $\begin{array}{l}\text { Change in the share of alignment votes with G7 countries on im- } \\
\text { portant UNGA votes between years t and t-1. Source: Kilby } \\
(2009 b)\end{array}$ & -0.020 & -0.023 \\
\hline$C H A N G E_{U S}^{I M P}$ & $\begin{array}{l}\text { Change in the share of alignment votes with the US on important } \\
\text { UNGA votes between years t and } t-1 \text {. Source: Kilby }(2009 b)\end{array}$ & 0.004 & 0.001 \\
\hline$P R O X I M I T Y_{G 7}^{A L L}$ & $\begin{array}{l}\text { Share of alignment votes with G7 countries on regular UNGA } \\
\text { votes. Source: Kilby }(2009 b)\end{array}$ & 0.648 & $0.623^{* *}$ \\
\hline$P R O X I M I T Y_{U S}^{A L L}$ & $\begin{array}{l}\text { Share of alignment votes with the US on regular UNGA votes. } \\
\text { Source: Kilby }(2009 b)\end{array}$ & 0.259 & 0.244 \\
\hline$P R O X I M I T Y_{G 7}^{I M P}$ & $\begin{array}{l}\text { Share of alignment votes with G7 countries on important UNGA } \\
\text { votes, as identified by the US State Department. Source: Kilby } \\
(2009 b)\end{array}$ & 0.635 & $0.592^{*}$ \\
\hline$P R O X I M I T Y_{U S}^{I M P}$ & $\begin{array}{l}\text { Share of alignment votes with the US on important UNGA votes, } \\
\text { as identified by the US State Department. Source: Kilby }(2009 b)\end{array}$ & 0.359 & $0.321^{*}$ \\
\hline$A F F I N I T Y$ & $\begin{array}{l}\text { Voting similarity in the UNGA with the US as measured by the } \\
\text { Affinity of Nations index. Source: Gartzke (1998). Data are avail- } \\
\text { able at http://dss.ucsd.edu/ egartzke/htmlpages/data.html: } \\
\text { Economic interests variables }\end{array}$ & -0.558 & -0.595 \\
\hline$B A N K S$ & $\begin{array}{l}\text { Total foreign banks' claims over GDP. Source: BIS consolidated } \\
\text { banking statistics, Table } 9 \mathrm{a}\end{array}$ & 0.226 & 0.333 \\
\hline$F D I$ & $\begin{array}{l}\text { Bilateral foreign direct investment (inflows) from G7 countries } \\
\text { over recipient GDP. Source: FDImarkets.com and WDI } \\
\text { Control variables }\end{array}$ & 0.011 & $0.025^{*}$ \\
\hline$G D P P C$ & Logarithm of GDP per capita (constant 2005 PPP). Source: WDI & 7.943 & $8.343^{* *}$ \\
\hline$C A B$ & Current account balance (\% GDP). Source: WDI & -0.105 & $-0.016^{* * *}$ \\
\hline$R E S E R V E$ & $\begin{array}{l}\text { Total reserves in months of imports. Source: WDI, IFS, IMF } \\
\text { country reports and national sources }\end{array}$ & 3.432 & $7.027^{* * *}$ \\
\hline GROWTH & $\begin{array}{l}\text { Gross domestic product, constant prices (annual percent change). } \\
\text { Source: WEO database }\end{array}$ & 0.055 & 0.063 \\
\hline \multicolumn{4}{|c|}{ Continued on next page } \\
\hline
\end{tabular}


Table 3: (continued)

\begin{tabular}{|c|c|c|c|}
\hline \multirow[t]{2}{*}{ VARIABLE } & \multirow[t]{2}{*}{ DESCRIPTION } & \multicolumn{2}{|c|}{ SAMPLE MEANS } \\
\hline & & $\begin{array}{l}\text { IMF pro- } \\
\text { gram }\end{array}$ & $\begin{array}{l}\text { No Pro- } \\
\text { gram }\end{array}$ \\
\hline INFLATION & $\begin{array}{l}\text { Inflation, average consumer prices (annual percent change). } \\
\text { Source: WEO database }\end{array}$ & 0.066 & 0.073 \\
\hline CORRUPTION & $\begin{array}{l}\text { Composite index of the control of corruption. Source: World Gov- } \\
\text { ernance Indicators (Kaufmann, Kraay and Mastruzzi, 2009) }\end{array}$ & -0.519 & -0.409 \\
\hline$G D P$ & $\begin{array}{l}\text { Logarithm of GDP (constant } 2005 \text { PPP). Source: World Develop- } \\
\text { ment Indicators (WDI) }\end{array}$ & 0.103 & $0.066^{* * *}$ \\
\hline QUOTA & Logarithm of the IMF quota. Source: IMF & -3.413 & $-2.748^{* *}$ \\
\hline $\begin{array}{l}\text { NON } \\
C O M P L I A N C E\end{array}$ & $\begin{array}{l}\text { Number of non-compliant years over total years with an arrange- } \\
\text { ment in place, 1990-2003. Source: Dreher and Walter (2010) }\end{array}$ & 0.365 & $0.204^{* * *}$ \\
\hline$S B A / E F F / F C L$ & $\begin{array}{l}\text { Dummy equal to one for countries with an SBA, EFF or FCL loan } \\
\text { agreement in place between Jan } 2008 \text { and Jun 2010. Source: IMF }\end{array}$ & 0.489 & n.a. \\
\hline$U N S C$ & $\begin{array}{l}\text { Temporary Member of the UN Security Council from } 2005 \\
\text { to 2007. Source: United Nations; data available at: } \\
\text { http://www.un.org/sc/members.asp }\end{array}$ & 0.089 & 0.110 \\
\hline$A I D$ & $\begin{array}{l}\text { Official development assistance from G7 countries ( } \% \text { GDP). } \\
\text { Source: OECD-DAC and WDI }\end{array}$ & 0.023 & 0.018 \\
\hline$T D S$ & Total debt service (\% GDP). Source: WDI & 0.035 & $0.052^{*}$ \\
\hline$D E B T$ & $\begin{array}{l}\text { Public and publicly guaranteed debt to private creditors (\% GDP). } \\
\text { Source: GDF }\end{array}$ & 0.343 & $0.260^{*}$ \\
\hline$O P E N N E S S$ & Total merchandise trade (\% GDP). Source: WDI & 0.751 & $0.693^{*}$ \\
\hline GLOBALIZATION & $\begin{array}{l}\text { KOF index of globalization in 2007. Source: Dreher (2006a), } \\
\text { updated in Dreher, Gaston and Martens (2008); data available } \\
\text { at: http://globalization.kof.ethz.ch./ }\end{array}$ & 51.483 & 52.235 \\
\hline$D E M O C R A C Y$ & $\begin{array}{l}\text { Dummy variable coded } 1 \text { if the regime qualifies as democratic. } \\
\text { Source: Cheibub, Gandhi and Vreeland (2010) }\end{array}$ & 0.533 & 0.493 \\
\hline & Selection variables & & \\
\hline ELECTION & $\begin{array}{l}\text { Dummy equal to } 1 \text { for countries with an election } 18 \text { months be- } \\
\text { fore the IMF loan or in } 2007 \text { for countries with no arrangements in } \\
\text { 2008-2010. Source: Database on Political Institutions 2009, up- } \\
\text { dated to } 2010 \text { (Beck et al., 2001) and Central Intelligence Agency } \\
\text { (2009) }\end{array}$ & 0.578 & $0.273^{* * *}$ \\
\hline EXISTING LOAN & $\begin{array}{l}\text { Dummy equal to one for countries with an IMF loan already in } \\
\text { place at Dec } 2007 \text { and which expires after May 31, 2008. Source: } \\
\text { IMF }\end{array}$ & 0.133 & 0.192 \\
\hline
\end{tabular}

Notes: Statistics are calculated on the sample of 118 low- and middle-income countries (Table 2), apart from variables for which there are missing values. When applicable, the last column reports the statistical significance of a one-tailed test of the null hypothesis that the values of the explanatory variables are different in program and non-program countries, with $* * *$ $\left({ }^{* *}\right)(*)$ indicating statistical significance at $1 \%(5 \%)(10 \%)$ level. Political similarity with the G7 is built by averaging the pairwise annual alignment scores in the UNGA. Variables are averaged over 2003-2007. Except where indicated otherwise, economic interests and control variables are measured in 2007 for countries without a lending arrangement or with an IMF loan agreed in 2008, and in 2008 for countries which have signed a lending arrangement since January 2009. 
Table 4: IMF lending in low- and middle-income countries: basic model

\begin{tabular}{|c|c|c|c|c|c|c|}
\hline & (1) & $(2)$ & (3) & $(4)$ & $(5)$ & (6) \\
\hline \multicolumn{7}{|c|}{ Outcome equation - Dep. Variable: $L O A N$ SIZE } \\
\hline$C A B$ & $\begin{array}{l}-0.024 \\
0.649]\end{array}$ & $\begin{array}{l}-0.025 \\
{[0.589]}\end{array}$ & $\begin{array}{l}-0.009 \\
{[0.844]}\end{array}$ & $\begin{array}{l}-0.033 \\
{[0.454]}\end{array}$ & $\begin{array}{c}0.01 \\
{[0.805]}\end{array}$ & $\begin{array}{l}-0.021 \\
{[0.615]}\end{array}$ \\
\hline \multirow[t]{2}{*}{$R E S E R V E$} & $0.007^{* *}$ & $0.006^{* *}$ & $0.007^{* * *}$ & $0.007^{* * * *}$ & $0.007 * * *$ & $0.006^{* * *}$ \\
\hline & & {$[0.017]$} & {$[0.003]$} & [0.003] & & {$[0.008]$} \\
\hline$G D P P C$ & $\left.\begin{array}{l}-0.012 \\
0.162]\end{array}\right]$ & $\begin{array}{l}-0.014^{*} \\
{[0.064]}\end{array}$ & $\begin{array}{l}-0.015^{*} \\
{[0.052]}\end{array}$ & $-0.020 * * *$ & $-0.018 * * *$ & $-0.016^{* *}$ \\
\hline \multirow{2}{*}{ GROWTH } & 0.216 & {$[0.004]$} & {$[0.052]$} & {$[0.009]$} & $\begin{array}{c}{[0.008]} \\
0.122\end{array}$ & $\begin{array}{c}{[0.027]} \\
0.092\end{array}$ \\
\hline & {$[0.133]$} & {$[0.225]$} & {$[0.495]$} & {$[0.232]$} & {$[0.264]$} & {$[0.433]$} \\
\hline \multirow[t]{2}{*}{$I N F L A T I O N$} & 0.039 & 0.062 & $0.119^{*}$ & $0.156^{* *}$ & $0.156^{* * *}$ & $0.119^{*}$ \\
\hline & [0.619] & {$[0.380]$} & {$[0.076]$} & {$[0.017]$} & {$[0.009]$} & {$[0.060]$} \\
\hline \multirow[t]{2}{*}{ CORRUPTION } & -0.007 & -0.008 & $-0.017^{*}$ & -0.013 & $-0.017 * *$ & -0.014 \\
\hline & {$[0.550]$} & {$[0.431]$} & {$[0.075]$} & {$[0.144]$} & {$[0.043]$} & {$[0.110]$} \\
\hline \multirow[t]{2}{*}{$G D P$} & $-0.026^{*}$ & $-0.029^{* * *}$ & $-0.021^{*}$ & $-0.024^{*}$ & -0.018 & -0.019 \\
\hline & {$[0.099]$} & [0.039] & {$[0.098]$} & {$[0.070]$} & {$[0.114]$} & {$[0.121]$} \\
\hline \multirow[t]{2}{*}{ QUOTA } & $0.035^{*}$ & $0.042^{* *}$ & $0.035^{* *}$ & $0.040 * *$ & $0.033^{* *}$ & $0.033^{* *}$ \\
\hline & $\begin{array}{c}{[0.069]} \\
-0.067 * * *\end{array}$ & $\begin{array}{c}{[0.012]} \\
-0.079^{* * *}\end{array}$ & $\begin{array}{c}{[0.023]} \\
-0.074 * * *\end{array}$ & $\begin{array}{c}{[0.015]} \\
-0.076 * *\end{array}$ & {$[0.018]$} & {$[0.027]$} \\
\hline$N O N-C O M P L I A N C E$ & $\begin{array}{c}-0.067 * * * \\
{[0.000]}\end{array}$ & $\begin{array}{c}-0.079^{* * *} \\
{[0.000]}\end{array}$ & $\begin{array}{c}-0.074^{* * *} \\
{[0.000]}\end{array}$ & $\begin{array}{c}-0.076^{* * *} \\
{[0.000]}\end{array}$ & $\begin{array}{c}-0.081^{* * *} \\
{[0.000]}\end{array}$ & $\begin{array}{c}-0.072^{* * *} \\
{[0.000]}\end{array}$ \\
\hline$S B A / E F F / F C L$ & $0.038 * * *$ & 0.01 & $\begin{array}{c}0.006 \\
{[0.651]}\end{array}$ & $\begin{array}{c}0.008 \\
{[0.519]}\end{array}$ & $\begin{array}{c}0.001 \\
{[0.929]}\end{array}$ & $\begin{array}{l}0.007 \\
{[0.563]}\end{array}$ \\
\hline CRISIS & & $\begin{array}{c}{[0.474]} \\
0.161^{* * *} \\
{[0.000]}\end{array}$ & $\begin{array}{c}{\left[0.172^{* * *}\right.} \\
{[0.000]}\end{array}$ & $\begin{array}{c}{[0.519} \\
0.230^{* * *} \\
{[0.000]}\end{array}$ & $\begin{array}{c}{[0.929]} \\
0.256^{* * *} \\
{[0.000]}\end{array}$ & $\begin{array}{c}0.141^{*} * * \\
{[0.001]}\end{array}$ \\
\hline$F R I E N D_{G 7}$ & & & $\begin{array}{l}-0.007 \\
{[0.361]}\end{array}$ & $\begin{array}{l}0.007 \\
{[0.569]}\end{array}$ & $\begin{array}{l}-0.007 \\
{[0.273]}\end{array}$ & $\begin{array}{l}-0.008 \\
{[0.273]}\end{array}$ \\
\hline$B A N K S$ & & & $\begin{array}{l}0.036^{* *} \\
{[0.030]}\end{array}$ & $\begin{array}{l}0.034^{* *} \\
{[0.029]}\end{array}$ & $\begin{array}{l}0.119^{* * *} \\
{[0.000]}\end{array}$ & $\begin{array}{l}0.032^{* *} \\
{[0.039]}\end{array}$ \\
\hline$F D I$ & & & $\begin{array}{l}0.195^{* *} \\
{[0.039]}\end{array}$ & $\begin{array}{l}0.223^{* *} \\
{[0.024]}\end{array}$ & $\begin{array}{c}0.190^{* *} \\
{[0.032]}\end{array}$ & $\begin{array}{l}-0.078 \\
{[0.674]}\end{array}$ \\
\hline$C R I S I S \times F R I E N D_{G 7}$ & & & & $\begin{array}{l}-0.103 \\
{[0.163]}\end{array}$ & & \\
\hline \multirow{2}{*}{\multicolumn{2}{|c|}{$C R I S I S \times F D I$}} & & & & $\begin{array}{c}-0.383^{* * *} \\
{[0.006]}\end{array}$ & \\
\hline & & & & & & $\begin{array}{c}3.528 \\
{[0.127]}\end{array}$ \\
\hline \multicolumn{7}{|c|}{ Selection equation - Dep. Variable: $\operatorname{Pr}(I M F L O A N)$} \\
\hline$C A B$ & $\begin{array}{c}-4.847^{* *} \\
{[0.024]}\end{array}$ & $\begin{array}{c}-4.150^{*} \\
{[0.062]}\end{array}$ & $\begin{array}{c}-6.775^{* *} \\
{[0.020]}\end{array}$ & $\begin{array}{c}-6.678^{* *} \\
{[0.033]}\end{array}$ & $\begin{array}{c}-6.825^{* *} \\
{[0.020]}\end{array}$ & $\begin{array}{c}-7.458^{* *} \\
{[0.018]}\end{array}$ \\
\hline$R E S E R V E$ & $\begin{array}{l}-0.168^{* *} \\
{[0.036]}\end{array}$ & $\begin{array}{c}-0.160^{* *} \\
{[0.044]}\end{array}$ & $\begin{array}{c}-0.218^{* *} \\
{[0.029]}\end{array}$ & $\begin{array}{c}-0.277^{* *} \\
{[0.014]}\end{array}$ & $\begin{array}{c}-0.241^{* *} \\
{[0.022]}\end{array}$ & $\begin{array}{c}-0.189^{*} \\
{[0.056]}\end{array}$ \\
\hline$G D P P C$ & $\begin{array}{l}-0.209 \\
{[0.475]}\end{array}$ & $\begin{array}{l}-0.249 \\
{[0.398]}\end{array}$ & $\begin{array}{l}-0.772^{*} \\
{[0.066]}\end{array}$ & $\begin{array}{l}-0.698 \\
{[0.113]}\end{array}$ & $\begin{array}{c}-0.734^{*} \\
{[0.085]}\end{array}$ & $\begin{array}{c}-0.927^{* *} \\
{[0.037]}\end{array}$ \\
\hline GROWTH & $\begin{array}{c}-15.115^{* *} \\
{[0.013]}\end{array}$ & $\begin{array}{c}-17.067^{* * *} \\
{[0.008]}\end{array}$ & $\begin{array}{c}-16.524^{* *} \\
{[0.022]}\end{array}$ & $\begin{array}{c}-20.005^{* *} \\
{[0.013]}\end{array}$ & $\begin{array}{c}-17.306^{* *} \\
{[0.019]}\end{array}$ & $\begin{array}{c}-19.732^{* *} \\
{[0.012]}\end{array}$ \\
\hline$I N F L A T I O N$ & $\begin{array}{c}9.122^{* *} \\
{[0.015]}\end{array}$ & $\begin{array}{c}8.951 * * \\
{[0.016]}\end{array}$ & $\begin{array}{c}8.727^{* *} \\
{[0.037]}\end{array}$ & $\begin{array}{l}8.328^{*} \\
{[0.065]}\end{array}$ & $\begin{array}{l}8.963 * * \\
{[0.036]}\end{array}$ & $10.954^{* *}$ \\
\hline CORRUPTION & -0.002 & 0.002 & 0.491 & 0.599 & 0.536 & 0.486 \\
\hline$G D P$ & {$[0.996]$} & $\begin{array}{c}{[0.996]} \\
0.669\end{array}$ & $\begin{array}{c}{[0.250]} \\
1.059\end{array}$ & $\begin{array}{l}{[0.201]} \\
1.364^{*}\end{array}$ & $\begin{array}{l}{[0.217]} \\
1.119^{*}\end{array}$ & $\begin{array}{l}{[0.278]} \\
1.200^{*}\end{array}$ \\
\hline$G D P$ & $\begin{array}{c}0.616 \\
{[0.283]}\end{array}$ & $\begin{array}{c}0.669 \\
{[0.257]}\end{array}$ & {$[0.115]$} & {$[0.055]$} & {$[0.096]$} & {$[0.089]$} \\
\hline QUOTA & -0.613 & -0.703 & -1.069 & $-1.482^{*}$ & -1.143 & -1.2 \\
\hline & {$[0.370]$} & {$[0.319]$} & {$[0.181]$} & {$[0.081]$} & {$[0.153]$} & {$[0.151]$} \\
\hline$N O N-C O M P L I A N C E$ & 0.787 & 0.869 & 0.446 & 0.533 & 0.398 & 0.374 \\
\hline & {$[0.250]$} & {$[0.211]$} & {$[0.574]$} & {$[0.517]$} & {$[0.618]$} & {$[0.640]$} \\
\hline$E L E C T I O N$ & $1.243^{* * * *}$ & $1.210^{* * *}$ & $1.887^{* * *}$ & $2.115^{* * *}$ & $1.958^{* * *}$ & $2.107^{* * *}$ \\
\hline$E X I S T I N G L O A N$ & $\begin{array}{c}{[0.000]} \\
-1.340^{* * *}\end{array}$ & $\begin{array}{c}{[0.001]} \\
-1.464^{* * *}\end{array}$ & $\begin{array}{c}{[0.000]} \\
-1.865^{* * *}\end{array}$ & $\begin{array}{c}{[0.000]} \\
-2.234^{* * *}\end{array}$ & $\begin{array}{c}{[0.000]} \\
-1.915^{* * *}\end{array}$ & $\begin{array}{c}{[0.000]} \\
-2.242 * * *\end{array}$ \\
\hline & {$[0.004]$} & {$[0.003]$} & {$[0.001]$} & {$[0.000]$} & {$[0.001]$} & {$[0.001]$} \\
\hline$C R I S I S$ & & 2.452 & 3.28 & -3.399 & 1.037 & $6.778^{*}$ \\
\hline & & {$[0.285]$} & {$[0.241]$} & {$[0.320]$} & {$[0.770]$} & {$[0.061]$} \\
\hline$F R I E N D_{G 7}$ & & & $\begin{array}{c}1.196^{* * *} * \\
{[0.009]}\end{array}$ & $\begin{array}{c}0.151 \\
{[0.808]}\end{array}$ & $\begin{array}{c}1.210^{* * *} * \\
{[0.010]}\end{array}$ & $\begin{array}{c}1.492^{* * *} * \\
{[0.004]}\end{array}$ \\
\hline$B A N K S$ & & & $\begin{array}{l}-0.747 \\
{[0.424]}\end{array}$ & $\begin{array}{l}-1.425 \\
{[0.201]}\end{array}$ & $\begin{array}{l}-1.995 \\
{[0.232]}\end{array}$ & $\begin{array}{l}-0.522 \\
{[0.580]}\end{array}$ \\
\hline$F D I$ & & & $-9.270^{* *}$ & $-11.014^{* * *}$ & $-9.012^{* *}$ & 19.593 \\
\hline & & & {$[0.018]$} & {$[0.009]$} & {$[0.027]$} & {$[0.277]$} \\
\hline$C R I S I S \times F R I E N D_{G 7}$ & & & & $\begin{array}{c}12.263^{* *} \\
{[0.011]}\end{array}$ & & \\
\hline$C R I S I S \times B A N K S$ & & & & & $\begin{array}{l}6.464 \\
{[0.349]}\end{array}$ & \\
\hline$C R I S I S \times F D I$ & & & & & & $\begin{array}{c}-355.167 \\
{[0.103]}\end{array}$ \\
\hline$\lambda$ & $\begin{array}{l}-0.014 \\
{[0.238]}\end{array}$ & $\begin{array}{c}-0.019^{*} \\
{[0.062]}\end{array}$ & $\begin{array}{c}-0.018^{* *} \\
{[0.039]}\end{array}$ & $\begin{array}{c}-0.01 \\
{[0.286]}\end{array}$ & $\begin{array}{l}-0.009 \\
{[0.326]}\end{array}$ & $\begin{array}{l}-0.011 \\
{[0.203]}\end{array}$ \\
\hline Observations & 118 & 118 & 118 & 118 & 118 & 118 \\
\hline Censored & 73 & 73 & 73 & 73 & 73 & 73 \\
\hline
\end{tabular}

Notes: The table reports regression coefficients and, in brackets, the associated standard errors. * significant at $10 \%,{ }^{*} 5 \%$, $* * * 1 \%$. The model is estimated by two-step Heckman, using Stata 11 SE package with HECKMAN command. A constant is included. 


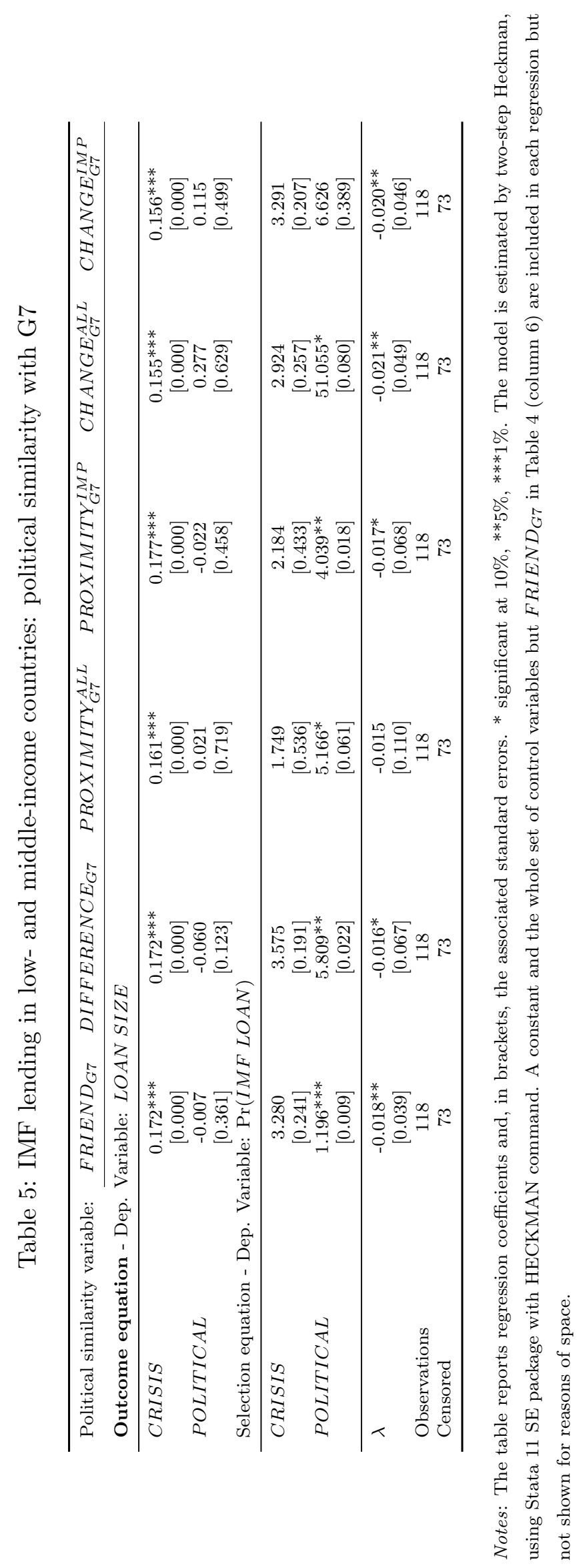




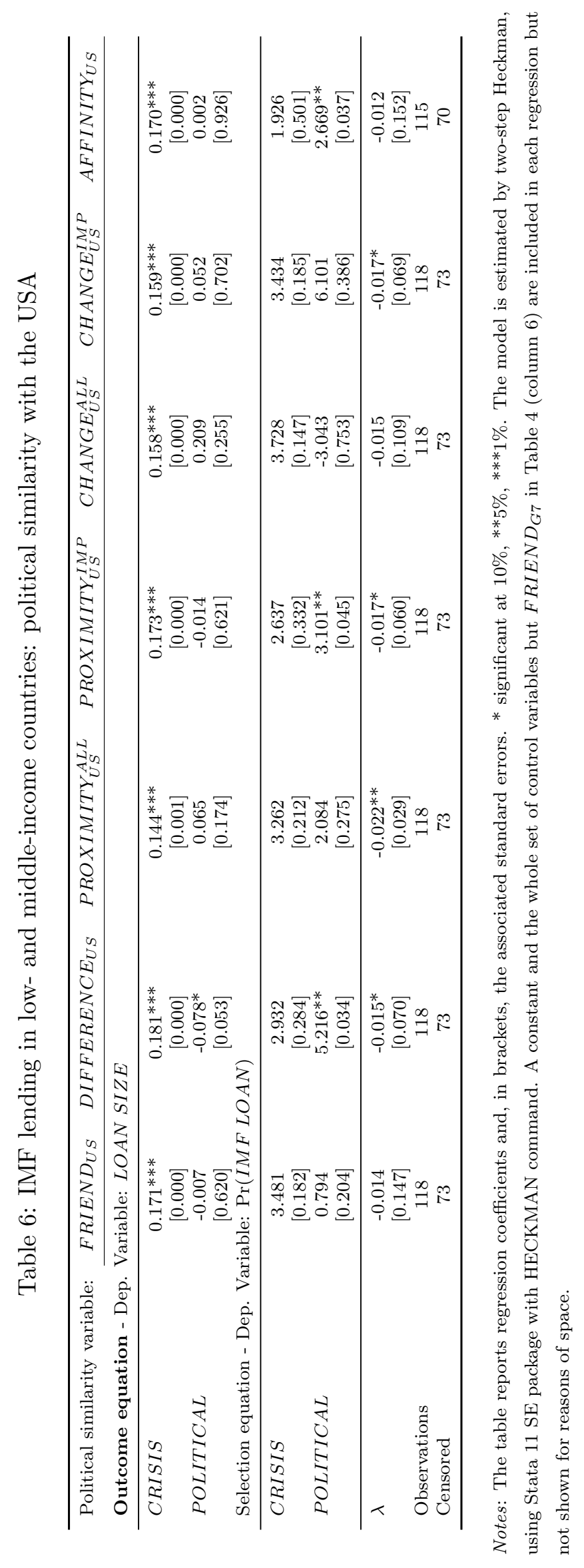




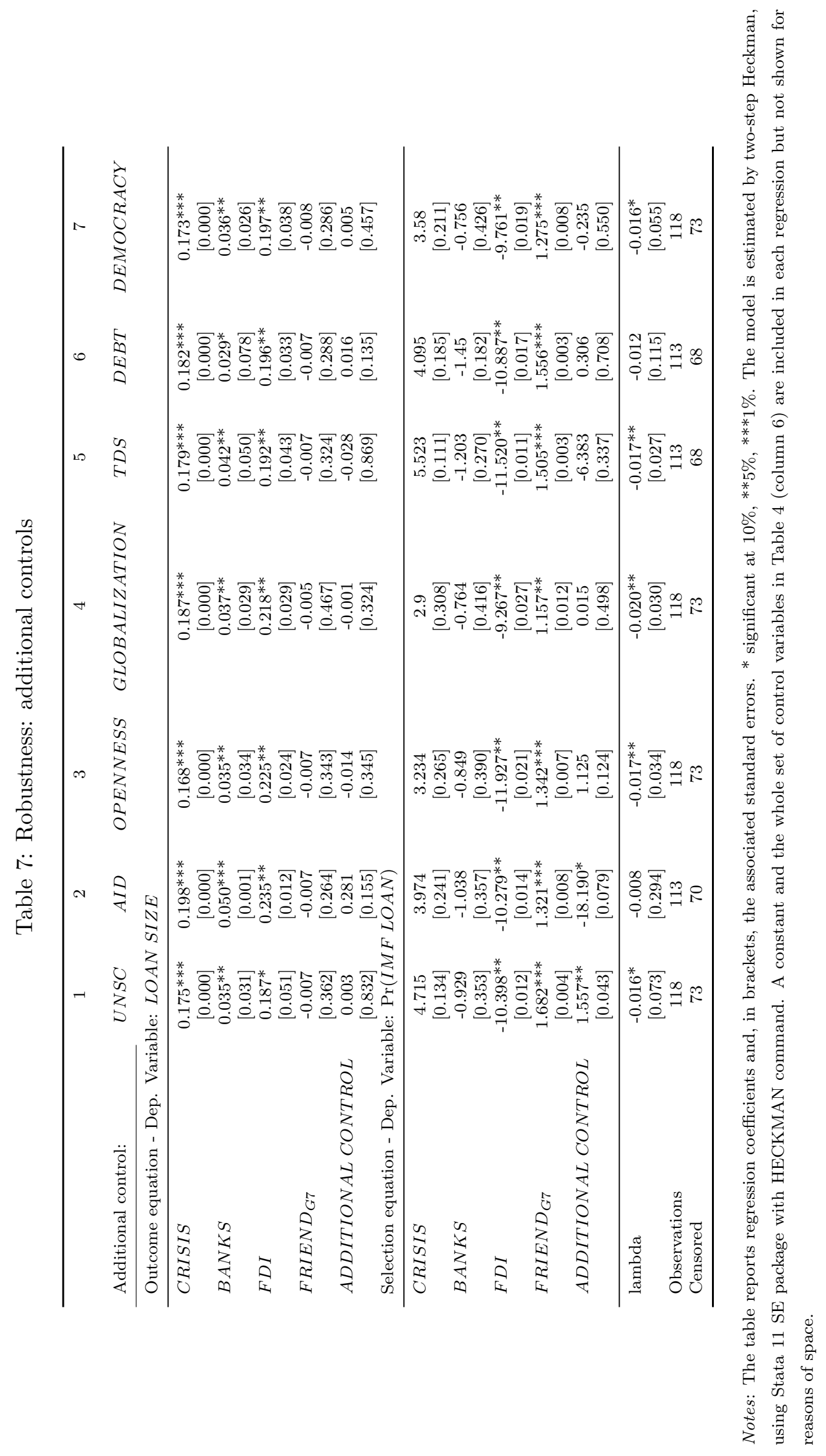


Table 8: Robustness: smaller sample without former Soviet republics

\begin{tabular}{|c|c|c|c|c|c|c|}
\hline & $(1)$ & $(2)$ & $(3)$ & $(4)$ & $(5)$ & (6) \\
\hline \multicolumn{7}{|c|}{ Outcome equation - Dep. Variable: LOAN SIZE } \\
\hline$C A B$ & $\begin{array}{l}-0.017 \\
{[0.697]}\end{array}$ & $\begin{array}{l}-0.019 \\
{[0.659]}\end{array}$ & $\begin{array}{l}-0.024 \\
{[0.519]}\end{array}$ & $\begin{array}{l}-0.034 \\
{[0.356]}\end{array}$ & $\begin{array}{l}-0.006 \\
{[0.898]}\end{array}$ & $\begin{array}{l}-0.025 \\
{[0.532]}\end{array}$ \\
\hline$R E S E R V E$ & $\begin{array}{c}0.003 \\
{[0.203]}\end{array}$ & $\begin{array}{c}0.003 \\
{[0.158]}\end{array}$ & $\begin{array}{c}0.008^{* * *} * \\
{[0.001]}\end{array}$ & $\begin{array}{c}0.007 * * * \\
{[0.002]}\end{array}$ & $\begin{array}{c}0.007 * * * \\
{[0.005]}\end{array}$ & $\begin{array}{c}0.008^{* * *} * \\
{[0.001]}\end{array}$ \\
\hline$G D P P C$ & $\begin{array}{c}-0.016^{* *} \\
{[0.034]}\end{array}$ & $\begin{array}{c}-0.016^{* *} \\
{[0.037]}\end{array}$ & $\begin{array}{l}-0.022^{* * * *} \\
{[0.001]}\end{array}$ & $\begin{array}{c}-0.025^{* * *} \\
{[0.000]}\end{array}$ & $\begin{array}{l}-0.022^{* * * *} \\
{[0.001]}\end{array}$ & $\begin{array}{c}-0.023^{* * *} \\
{[0.001]}\end{array}$ \\
\hline GROWTH & $\begin{array}{c}0.031 \\
{[0.824]}\end{array}$ & $\begin{array}{c}0.070 \\
{[0.615]}\end{array}$ & $\begin{array}{l}-0.030 \\
{[0.796]}\end{array}$ & $\begin{array}{l}-0.026 \\
{[0.832]}\end{array}$ & $\begin{array}{l}-0.045 \\
{[0.698]}\end{array}$ & $\begin{array}{l}-0.040 \\
{[0.746]}\end{array}$ \\
\hline$I N F L A T I O N$ & $\begin{array}{c}0.054 \\
{[0.415]}\end{array}$ & $\begin{array}{c}0.058 \\
{[0.378]}\end{array}$ & $\begin{array}{c}0.200^{* * *} \\
{[0.001]}\end{array}$ & $\begin{array}{c}0.214^{* * * *} \\
{[0.000]}\end{array}$ & $\begin{array}{c}0.193^{* * *} * \\
{[0.002]}\end{array}$ & $\begin{array}{c}0.201 * * * \\
{[0.001]}\end{array}$ \\
\hline CORRUPTION & $\begin{array}{c}0.004 \\
{[0.728]}\end{array}$ & $\begin{array}{c}0.001 \\
{[0.914]}\end{array}$ & $\begin{array}{l}-0.009 \\
{[0.274]}\end{array}$ & $\begin{array}{l}-0.007 \\
{[0.417]}\end{array}$ & $\begin{array}{l}-0.009 \\
{[0.277]}\end{array}$ & $\begin{array}{l}-0.009 \\
{[0.305]}\end{array}$ \\
\hline$G D P$ & $\begin{array}{l}-0.025^{*} \\
{[0.077]}\end{array}$ & $-0.025^{*}$ & $\begin{array}{c}-0.025^{* *} \\
{[0.028]}\end{array}$ & $\begin{array}{c}-0.023^{* *} \\
{[0.044]}\end{array}$ & $\begin{array}{l}-0.021^{*} \\
{[0.089]}\end{array}$ & $\begin{array}{c}-0.024^{* *} \\
{[0.034]}\end{array}$ \\
\hline QUOTA & $\begin{array}{l}0.031^{*} \\
{[0.079]}\end{array}$ & $\begin{array}{l}0.034^{* *} \\
{[0.050]}\end{array}$ & $\begin{array}{l}0.039^{* * *} \\
{[0.006]}\end{array}$ & $\begin{array}{c}0.038^{* *} \\
{[0.010]}\end{array}$ & $\begin{array}{l}0.034^{* *} \\
{[0.034]}\end{array}$ & $\begin{array}{c}0.038^{* * *} * \\
{[0.008]}\end{array}$ \\
\hline$N O N-C O M P L I A N C E$ & $\begin{array}{c}-0.053^{* * *} \\
{[0.002]}\end{array}$ & $\begin{array}{c}-0.062^{* * *} \\
{[0.000]}\end{array}$ & $\begin{array}{c}-0.060^{* * *} * \\
{[0.000]}\end{array}$ & $\begin{array}{c}-0.061^{* * *} \\
{[0.000]}\end{array}$ & $\begin{array}{c}-0.060^{* * *} \\
{[0.000]}\end{array}$ & $\begin{array}{c}-0.059^{* * *} \\
{[0.000]}\end{array}$ \\
\hline$S B A / E F F / F C L$ & $\begin{array}{l}0.041^{* * * *} \\
{[0.002]}\end{array}$ & $\begin{array}{l}0.027^{*} \\
{[0.078]}\end{array}$ & $\begin{array}{c}0.016 \\
{[0.205]}\end{array}$ & $\begin{array}{c}0.019 \\
{[0.150]}\end{array}$ & $\begin{array}{c}0.017 \\
{[0.191]}\end{array}$ & $\begin{array}{l}0.018 \\
{[0.174]}\end{array}$ \\
\hline$C R I S I S$ & & $\begin{array}{c}0.080 \\
{[0.106]}\end{array}$ & $\begin{array}{c}0.091 * * \\
{[0.028]}\end{array}$ & $\begin{array}{l}0.113^{*} \\
{[0.057]}\end{array}$ & $\begin{array}{c}0.124^{* *} \\
{[0.024]}\end{array}$ & $\begin{array}{l}0.086^{*} \\
{[0.057]}\end{array}$ \\
\hline$F R I E N D_{G 7}$ & & & $\begin{array}{c}0.002 \\
{[0.756]}\end{array}$ & $\begin{array}{c}0.006 \\
{[0.559]}\end{array}$ & $\begin{array}{c}0.001 \\
{[0.929]}\end{array}$ & $\begin{array}{c}0.002 \\
{[0.747]}\end{array}$ \\
\hline$B A N K S$ & & & $\begin{array}{c}0.067^{* * *} * \\
{[0.000]}\end{array}$ & $\begin{array}{c}0.066 * * * \\
{[0.000]}\end{array}$ & $\begin{array}{c}0.100 * * \\
{[0.016]}\end{array}$ & $\begin{array}{c}0.066 * * * \\
{[0.000]}\end{array}$ \\
\hline$F D I$ & & & $\begin{array}{l}0.179^{* *} \\
{[0.030]}\end{array}$ & $\begin{array}{c}0.181 * * \\
{[0.036]}\end{array}$ & $\begin{array}{l}0.164^{*} \\
{[0.051]}\end{array}$ & $\begin{array}{c}0.150 \\
{[0.364]}\end{array}$ \\
\hline$C R I S I S \times F R I E N D_{G 7}$ & & & & $\begin{array}{l}-0.036 \\
{[0.625]}\end{array}$ & & \\
\hline$C R I S I S \times B A N K S$ & & & & & $\begin{array}{l}-0.188 \\
{[0.388]}\end{array}$ & \\
\hline$C R I S I S \times F D I$ & & & & & & $\begin{array}{c}0.125 \\
{[0.957]}\end{array}$ \\
\hline Selection equation - Dep. V & riable: $\operatorname{Pr}(I$ & $F L O A N)$ & & & & \\
\hline$C A B$ & $\begin{array}{c}-4.419^{* *} \\
{[0.045]}\end{array}$ & $\begin{array}{c}-4.148^{*} \\
{[0.067]}\end{array}$ & $\begin{array}{c}-6.550^{* *} \\
{[0.024]}\end{array}$ & $\begin{array}{c}-5.754^{*} \\
{[0.063]}\end{array}$ & $\begin{array}{c}-6.371^{* *} \\
{[0.025]}\end{array}$ & $\begin{array}{c}-6.928^{* *} \\
{[0.026]}\end{array}$ \\
\hline$R E S E R V E$ & $\begin{array}{c}-0.162^{*} \\
{[0.052]}\end{array}$ & $\begin{array}{c}-0.158^{*} \\
{[0.057]}\end{array}$ & $\begin{array}{c}-0.212^{* *} \\
{[0.045]}\end{array}$ & $\begin{array}{c}-0.266^{* *} \\
{[0.033]}\end{array}$ & $\begin{array}{c}-0.228^{* *} \\
{[0.036]}\end{array}$ & $\begin{array}{l}-0.171 \\
{[0.101]}\end{array}$ \\
\hline$G D P P C$ & $\begin{array}{l}-0.281 \\
{[0.349]}\end{array}$ & $\begin{array}{l}-0.291 \\
{[0.331]}\end{array}$ & $\begin{array}{c}-0.788^{*} \\
{[0.070]}\end{array}$ & $\begin{array}{c}-0.856^{*} \\
{[0.070]}\end{array}$ & $\begin{array}{c}-0.746^{*} \\
{[0.092]}\end{array}$ & $\begin{array}{c}-0.932^{* *} \\
{[0.042]}\end{array}$ \\
\hline GROWTH & $\begin{array}{c}-16.822^{* * *} \\
{[0.009]}\end{array}$ & $\begin{array}{l}-17.471^{* * *} \\
{[0.008]}\end{array}$ & $\begin{array}{l}-16.997^{* *} \\
{[0.021]}\end{array}$ & $\begin{array}{c}-20.087^{* *} \\
{[0.017]}\end{array}$ & $\begin{array}{l}-16.797^{* *} \\
{[0.024]}\end{array}$ & $\begin{array}{c}-19.430^{* *} \\
{[0.014]}\end{array}$ \\
\hline INFLATION & $\begin{array}{c}8.570^{* *} \\
{[0.026]}\end{array}$ & $\begin{array}{c}8.464^{* *} \\
{[0.027]}\end{array}$ & $\begin{array}{l}7.784^{*} \\
{[0.070]}\end{array}$ & $\begin{array}{c}7.421 \\
{[0.117]}\end{array}$ & $\begin{array}{l}7.908^{*} \\
{[0.069]}\end{array}$ & $\begin{array}{c}9.791^{* *} \\
{[0.028]}\end{array}$ \\
\hline CORRUPTION & $\begin{array}{l}-0.01 \\
{[0.978]}\end{array}$ & $\begin{array}{l}-0.013 \\
{[0.973]}\end{array}$ & $\begin{array}{l}0.497 \\
{[0.261]}\end{array}$ & $\begin{array}{c}0.736 \\
{[0.129]}\end{array}$ & $\begin{array}{c}0.546 \\
{[0.222]}\end{array}$ & $\begin{array}{c}0.512 \\
{[0.263]}\end{array}$ \\
\hline$G D P$ & $\begin{array}{c}0.511 \\
{[0.406]}\end{array}$ & $\begin{array}{c}0.54 \\
{[0.385]}\end{array}$ & $\begin{array}{c}0.942 \\
{[0.182]}\end{array}$ & $\begin{array}{l}1.235 \\
{[0.103]}\end{array}$ & $\begin{array}{c}0.943 \\
{[0.180]}\end{array}$ & $\begin{array}{l}1.065 \\
{[0.145]}\end{array}$ \\
\hline QUOTA & $\begin{array}{l}-0.483 \\
{[0.513]}\end{array}$ & $\begin{array}{c}-0.53 \\
{[0.478]}\end{array}$ & $\left.\begin{array}{c}-0.92 \\
{[0.276]}\end{array}\right]$ & $\begin{array}{l}-1.335 \\
{[0.149]}\end{array}$ & $\begin{array}{l}-0.934 \\
{[0.269]}\end{array}$ & $\begin{array}{l}-1.038 \\
{[0.234]}\end{array}$ \\
\hline$N O N-C O M P L I A N C E$ & $\begin{array}{c}0.645 \\
{[0.366]}\end{array}$ & $\begin{array}{c}0.698 \\
{[0.335]}\end{array}$ & $\begin{array}{l}0.37 \\
{[0.649]}\end{array}$ & $\begin{array}{c}0.406 \\
{[0.642]}\end{array}$ & $\begin{array}{l}0.323 \\
{[0.695]}\end{array}$ & $\begin{array}{l}0.351 \\
{[0.666]}\end{array}$ \\
\hline$E L E C T I O N$ & $\begin{array}{c}1.224 * * * \\
{[0.001]}\end{array}$ & $\begin{array}{c}1.208^{* * *} * \\
{[0.001]}\end{array}$ & $\begin{array}{c}1.821^{* * * *} \\
{[0.000]}\end{array}$ & $\begin{array}{c}1.970^{* * *} * \\
{[0.000]}\end{array}$ & $\begin{array}{c}1.819 * * * \\
{[0.000]}\end{array}$ & $\begin{array}{c}1.937^{* * *} * \\
{[0.000]}\end{array}$ \\
\hline$E X I S T I N G L O A N$ & $\begin{array}{l}-1.250^{* * *} \\
{[0.008]}\end{array}$ & $\begin{array}{l}-1.317^{* * *} \\
{[0.008]}\end{array}$ & $\begin{array}{l}-1.734^{* * *} * \\
{[0.002]}\end{array}$ & $\begin{array}{c}-2.174^{* * *} \\
{[0.001]}\end{array}$ & $\begin{array}{c}-1.766^{* * *} \\
{[0.002]}\end{array}$ & $\begin{array}{l}-2.048^{* * *} \\
{[0.001]}\end{array}$ \\
\hline CRISIS & & $\begin{array}{l}1.215 \\
{[0.655]}\end{array}$ & $\begin{array}{c}2.836 \\
{[0.390]}\end{array}$ & $\begin{array}{l}-6.945 \\
{[0.185]}\end{array}$ & $\begin{array}{l}1.175 \\
{[0.765]}\end{array}$ & $\begin{array}{l}6.561 \\
{[0.110]}\end{array}$ \\
\hline$F R I E N D_{G 7}$ & & & $\begin{array}{l}1.128^{* *} \\
{[0.016]}\end{array}$ & $\begin{array}{l}-0.437 \\
{[0.545]}\end{array}$ & $\begin{array}{l}1.136^{* *} \\
{[0.016]}\end{array}$ & $\begin{array}{c}1.401 * * * \\
{[0.007]}\end{array}$ \\
\hline$B A N K S$ & & & $\begin{array}{l}-0.777 \\
{[0.440]}\end{array}$ & $\begin{array}{l}-1.336 \\
{[0.316]}\end{array}$ & $\begin{array}{c}-2.28 \\
{[0.327]}\end{array}$ & $\begin{array}{l}-0.457 \\
{[0.649]}\end{array}$ \\
\hline$F D I$ & & & $\begin{array}{l}-8.940^{* *} \\
{[0.024]}\end{array}$ & $\begin{array}{c}-12.263^{* * *} \\
{[0.006]}\end{array}$ & $-8.783^{* *}$ & 18.254 \\
\hline$C R I S I S \times F R I E N D_{G 7}$ & & & & $\begin{array}{c}20.359^{* * *} \\
{[0.006]}\end{array}$ & & \\
\hline$C R I S I S \times B A N K S$ & & & & & $\begin{array}{c}8.168 \\
{[0.463]}\end{array}$ & \\
\hline$C R I S I S \times F D I$ & & & & & & $\begin{array}{c}-332.572 \\
{[0.139]}\end{array}$ \\
\hline$\lambda$ & $\begin{array}{l}-0.004 \\
{[0.661]}\end{array}$ & $\begin{array}{l}-0.008 \\
{[0.396]}\end{array}$ & $\begin{array}{l}-0.007 \\
{[0.339]}\end{array}$ & $\begin{array}{l}-0.001 \\
{[0.947]}\end{array}$ & $\begin{array}{l}-0.005 \\
{[0.585]}\end{array}$ & $\begin{array}{l}-0.006 \\
{[0.379]}\end{array}$ \\
\hline Observations & 107 & 107 & 107 & 107 & 107 & 107 \\
\hline Censored & 69 & 69 & 69 & 69 & 69 & 69 \\
\hline
\end{tabular}

Notes: The table reports regression coefficients and, in brackets, the associated standard errors. * significant at $10 \%, * * 5 \%$, *** $1 \%$. The model is estimated by two-step Heckman, using Stata 11 SE package with HECKMAN command. A constant is included. 